\title{
Televizyon Haberlerinde Garbiyatçılık: TRT Örneği ${ }^{*}$
}

\author{
Occidentalism in Television News Reporting: The Case of TRT
}

\author{
Devrim İNCE, Türkiye, devrimince@gmail.com
}

\begin{abstract}
Öz: Bu çalışmada, Türkiye Radyo Televizyon Kurumu (TRT) haberlerinde Batı fikrinin nasıl üretildiği incelenmiştir. Çalışma, Batı ve Doğu kavramlarının coğrafi bir ayrımdan öte, bir sinıflama ve kategorizasyon sistematiği içerdiği görüşüne dayanmaktadır. Çalışmanın kavramsal çerçevesini olușturan Garbiyatçıllk, Batı imgesinin iktidar sağlamak amacıyla olumlu ya da olumsuz anlamda üretimi olarak ele alınmıștır. Yapılan çerçeveleme analizi sonucu, televizyon haberlerinde Batı fikrinin "tanımlama-ontolojik ayrım yapma"ve "muhayyel bir "biz" oluşturmaya"yönelik iki temel çerçevede üretildiği anlaşılmıştır. Ayrıca, analiz sonucunda haberlerde üretilen Batı imgesinin yapılandırllmasındasiyasi elitlerin hegemonik bir ă̆ırlğg bulunduğu görülmektedir. Bunun yanında televizyon haberlerinde inşa edilen Batı fikrinin, iç politikayı şekillendirme ve yönlendirme amacıyla araçsallaştırıldı̆̆ göze çarpmaktadır.
\end{abstract}

Anahtar Sözcükler:Garbiyatçılık, Türkiye'de Batıcılık, Çerçeveleme, TRT.

\begin{abstract}
This study examines the production of the idea of West in the news of the Turkish Radio and Television Corporation (TRT). The article is based on the idea that the classification between the East and the West consists of a categorization practise, more than a geographical distinction. The concept of Occidentalism, as the theoretical framework of the study, is probed as the negative or positive production of the idea of the West that provide power. The result of framing analysis in the study indicates that the idea of the West in the news are produced in two fundamental frames which consist of "the frame to describe the West and stress the ontological distinction" and "the frame to conceptualise an imaginative "us". The results of the study also show that the political elites have a hegemonic position in the construction of the idea of the West. It is also a fact that the image of the West constructed in the news are instrumentalised to shape and manipulate domestic policies.
\end{abstract}

Keywords: Occidentalism, Westernization in Turkey, Framing, TRT.

\section{Giriş}

"Garp/Batı",üç yüzyıla yaklaşan Türk modernleşme tarihi içinde en sık telaffuz edilen kavramlarından biridir. "Pergelin sabit ucu" olarak Batı, Türkiye'deki fikir hareketlerinin tamamı üzerinde etkili olmuştur. Batı imgesinin, Batı ile karşılaşmaların niteliği değiştikçe, yeniden üretildiğini, tekrarlandığını, anımsandığını söylemek mümkündür. Batı, “İslam dışı”, fethedilmesi gereken bir coğrafya olmaktan çıkıp, önce üstünlüğü kabul edilen, sonra da taklit edilmesi gereken bir arzu nesnesine dönüşmüştür (Lewis 1983, 35;Bkz. Göle 2004).Ülkenin kurtuluşu ve bekası için modernleşme çabası bağlamında araçsallaştırılan Batı fikri, toplum içindeki kimliksel yarılmaların ve uzun yıllara yayılacak bir "kültürel şizofreni”nin (Bkz. Shayegan, 1991) de nedeni olmuştur.

Bu çalışma, Türkiye'de özerk statüdeki kamu yayın kurumuTRT'nin ${ }^{1}$ ana haber bültenlerinde Batı fikrinin nasıl inşa edildiği sorusuna yanıt aramıştır. Çalışmanın içeriği, kavramsal çerçeve, tarihsel arka plan ve araştırmayı içeren birbiriyle bağlantılı üç bölümden oluşmaktadır."Batı bilgisinin genelleme/soyutlama ve nesneleştirmeye dayalı üretimi"” olarak özetleyebileceğimiz (Bkz. Chen 1995, Venn 2000, Boer 2009) Garbiyatç1lık düşüncesi, kavramsal çerçeveyi oluşturmuştur. Sosyal alanın verili ve kanıtlanabilir bir yapı olarak değil, anlaşılabilir ve gösterilebilir bir olgu olarak ele alındığı bu çalışma, tüm olguların tarihsellikleriyle anlaşılabileceği düşüncesine dayanmaktadır. Garbiyatçılık, bu temelde ve araştırma sorusuna uygun biçimde kavramsallaştırılmıştır.

Araştırma, 4 ay boyunca TRT Haber'de yayınlanan toplam 86 saat 42 dakikalık haber bülteninin içerik çözümlemesi metodu ile incelenmesine dayanmaktadır. Televizyon haberleri, bu çalışmada gerçekliğin bir yönünü içerip, bir bölümünü ise kadrajın dışında bırakan bir anlatı olarak görülmüş; haber metninin, olay ve olguları çerçevelemeye yönelimli olduğu savı benimsenmiştir. Çözümlemede ilk olarak haber metninin makro niteliklerine odaklanılmış ve veriler, çerçeveleme yaklaşımından hareketle yorumlanmıştır. Burada amaç, haberleri, kaynaklar ve haber aktörleri bağlamında incelemek; haber metninin içeriğindeki süreksiz(episodic)-tematik, ahlaki-teknik çerçeveler aracılığıyla Batı anlatısına yüklenen moral değerleri, iktidar ilişkisi bağlamında sorgulamaktır. Sonraki aşamada ise, televizyon haberlerinde Batı fikrinin hangi temel kategoriler çerçevesinde inşa edildiğini anlamak ve haberlerdeki Garbiyatçı öğelerin, Türk siyasi düşüncesindeki Batı imgesi ile etkileşimine dikkat çekmekamaçlanmıştır. Bu nedenle bulgular, bu çalışmaya özgü oluşturulan "konu odaklı çerçevelemeler" temelinde yorumlanmıştır.

Garbiyatçlık kavramı, sosyal bilimler alanındaki çeşitli çalışmalara konu olmakla birlikte, konuyu televizyon haberciliği ve iletişim metninin çözümlenmesi bağlamında ele alan bir çalışma henüz bulunmamaktadır. Çalışma, Türkiye'de televizyon haberlerindeki Garbiyatçı anlatının inşasına odaklanan ilk çalışma olacaktır. Araştırmanın

*Bu makale, yazarın Ege Üniversitesi Sosyal Bilimler Enstitüsü Radyo-TV ve Sinema Anabilim Dalı'nca kabul edilen “Televizyon Haberlerinde Gerçekliğin İnşası ve Garbiyatçılık Sorunsalı: TRT Örneği” başlıklı doktora tezinden derlenmiştir.

${ }^{1}$ Türkiye Radyo Televizyon Kurumu, kamu bütçesinden finanse edilmesine karşın 1993 yılında TBMM kararıyla Anayasal özerklik tanınmıș bir statüye sahiptir. Ancak, editoryal olarak tarafsızlığı ve özerkliği tartışma konusu olabilmektedir.. 
televizyon haberlerinde Garbiyaţ̧ı düşüncenin nasıl çerçevelendiğini ortaya çıkarmak kadar, Türk siyasal düşüncesinin her tonuna geniş bir manevra sahası yaratan bu durumu sosyo-politik ve tarihsel özellikleri ile analiz ederek alana katkı sağlaması hedeflenmektedir.

\title{
2. Kavramsal Çerçeve: Garbiyatçılık
}

Garbiyatçıllı̆̆ı kavramsallaştırılmasında, Edward Said'in geçtiğimiz yüzyılda "Şarkiyatçılık" meselesine getirdiği kapsamlı yorum, önemli bir çıkış noktası olarak görülebilir. Şarkiyatçıllığı, "Doğu'ya ait nötr bilgiler" gibi bir içeriktenibaret görmek yerine hegemonik güçlerin diş siyaset, özellikle de yayılmacılık hedeflerini gerçekleştirebilmek için ürettikleri bir tür ideoloji olarak yeniden tanımladığında Said, Şarkiyatçılığın temel olarak epistemolojik ve ontolojik bir ayrımadayandığına dikkat çekmiş, bu girişimi bir tür "imgesel coğrafya sınırı koymak" şeklinde adlandırmıştır(2003,12-59-75). "Doğu", "Batılı"lar tarafından stratejik amaçlarına uygun biçimde "Doğulu"laştırılmış, Şarkiyatçılık "sömürgeciliğin keşif kolu" olarak işe koşulmuştur (Said 2003, 59).Batı'nın dünyanın geri kalanı üzerinde kurduğu ekonomik ve kültürel hegemonya, bilgi inşa sürecinde de ayrıcalığın onda olmasını sağlamıştır. Bu ayrıcalığı yaratan ana neden ise, akıl ve bilimin kutsallaştırıldığı pozitivist bir dünya düzeni aracıllğıyla oluşturulan, Batı'nın teknik ve uygarlığına duyulan sonsuz inançtır. Modern Batı uygarlı̆̆ı, sezgi ve inancın karşısına aklı; gelenek ve dinin karşısına teknik ve bilimi ikame etmiştir.

Maddi gelişme ve aklı merkeze alan bu yapı üzerine ilk itirazlar, Romantizm vb. Batı kaynaklı kimi düşünce ekolleri tarafından geliştirildiyse de, litaratüre bakıldığında eleştirinin "Batı-dışı" ilk kapsamlı halinin post-kolonyalizm çalışmalarından geldiğini söylememiz mümkündür. Batı kolonisi olarak Batı'nın kendileri hakkında ürettiği bilginin aynasında yaşamaya mahkûm edilmiş "madunlar", teorik ve pratik çalışmalar aracılığıyla "Batı" üzerine söz söylemeye başlamışıtır (Chatterjee, 1996). Sonrasında "ikincil" bir sömürü ilişkisi üzerinden, Batı modernleşmesine maruz kalmış İslâm dünyasının kimi bölgelerinden itiraz, red, aşağılama, nefret, arzu, merak benzeri birçok tavrın kesişiminden oluşan "Garp" tahayyülleri ortaya çıkmıştır. Aslında Said, Batı'nın Doğu'ya egemen oluşunda, bir bilgi-iktidar ilişkisi kurduğundan ve hâkimiyetini böyle inşa ettiğinden söz ederken, okurun düşeceği açmazı sezer gibi kitabının sonunda şu cümlelere yer verir:

\begin{abstract}
“(...) Şarkiyatçıllı̆a verilecek yanıtın Garbiyatçılık olmadığını göstermiş olduğumu umuyorum. Hiçbir eski "Şarklı", bu Şarklılığı yaşamış olduğu için, şimdi kendisinin ürettiği yeni "Şarklılar"1 - ya da "Garplılar"1 incelemeye yatkın olduğu düşüncesiyle rahatlamamalı. (Said 2003, 343)"
\end{abstract}

Şarkiyatçılığın yarattığı yıkım ve zihinsel tahribatı incelikle deşifre eden Said'in Garbiyatçılık’tanda sadece "emperyalizme karşı direniş" gibi bir anlam çıkarmadığı ortadadır. Nitekim, çekincesi boşa çıkmamış, gelinen noktada, Garbiyatçılığın popüler yorumu, özellikle de Şark'ta, Şarkiyatçılığın karşıt ikizi olarak konumlandırılmaya yönelik olmuştur. Misırlı felsefeci Hasan Hanefi'ye göre, "Oryantalizm, merkezin bir ürünü ise Oksidentalizm de çevrenin bir ürünüdür... Oryantalizmin tersine meşru ve haklıdır (2006, 81)." Garbiyatçıllğı, "tersine Şarkiyatçılık" olarak gören İranlı siyaset bilimci Mehrzad Boroujerdi ise, kavramı Doğulu entelektüellerin gerçek kimliklerini yeniden ele geçirmek için kullandıkları bir söylem olarak tanımlamaktadır(2001, 37).̇̇lk garbiyatçıların, Şarkiyatçılığın kendileri için uygun gördüğü yeri - ontolojik nesne olma konumunu, Doğululaştırılmayı - zımni olarak kabullendiği ve sorunu sadece siyasi düzeyde bir hak aramaya indirgediği söylenebilir. Ancak, Hanefi'den birkaç yıl sonraXiaomei Chen, Garbiyatçllık düşüncesini stratejik bir karşı söylem olarak ele almış ve Garbiyatçıllı̆ı Batı fikrinin Batı dışında yeniden tanımlanması olarak nitelendirmiştir $(1995,5)$. Benzer biçimde Couezze Venn de sömürgeci ile sömürgeleştiren arasındaki eşitsiz ilişki pratiğine dikkat çekerek Garbiyatçıllı̆ı "Modernitenin sömürgeleştirilen toplumlar tarafindan anlaşılan kısmı" olarak görmektedir $(2000,19)$. Anlaşıldığ olarak görenler ile Şarkiyatçılık gibi Garbiyatçılığın da bir homojenleştirme, ayrım yaratma potansiyeli taşıdığını savunanlar arasında köklü bir teorik ayrılık bulunmaktadır.

Garbiyatçılık kavramının popülerlik kazanması ise Buruma ve Margalit'in kitabından (2009) sonra olmuştur. Garbiyatçıllğın "basit bir önyargılar demeti” olarak açıklanamayacağını savunan Buruma ve Margalit, kavramın temelinde Batı tarzı düşünmeye yönelik sistematik bir tepkinin yattığına dikkat çekmekte, zaman zaman Rus ruhu, Alman ırkı, komünizm, anti-emperyalizm ve din adına Batı tarzı düşünme biçimine açılan savaşlar olduğundan söz etmektedir (2009,55). Aynı paraleldeki bir diğer yaklaşım ise Leen Boer'den gelmiştir. Boer de Garbiyatçılık kavramını "entelektüel tahribatın bir biçimi" olarak tanımlamayı önermektedir. İslâmcılık, Avrupa-merkezcilik, liberalizm ve garbiyatçılığı "izm'lerle mücadele" bağlamında eleştiren Leen Boer'e göre Garbiyatçılık bir de-humanizasyon sürecidir: "Batı, değerler rasyonelitesi az, ancak araçsal akılcılığı fazla olarak resmedilir. Batı zihni böylelikle yüksek düzeyde bir aptallık olarak görülür. Aritmetik hesaplar yapmak için özel bir yeteneğe sahip bu zihin, insani açıdan önemli şeyleri yapmada umutsuz vakadır $(2004,152) . "$

Direniş̧̧i ve öz-savunmacı bir nitelik de taşımakla birlikte; Garbiyatçılığı, bu çalışmada da yapıldığı gibi, Şarkiyatçıllk gibi epistemolojik ve ontolojik bir fark üreten, imgesel coğrafya sınırı koyma girişimi olarak da değerlendirmek mümkündür. 


\section{Türk Siyasi Düşüncesinde Batı Algısı}

Osmanlı-Türk fikir hayatında Batı üzerine etraflıca düşünmenin, İmparatorluğun askeri alanda geri çekilmek zorunda kalmasıyla eşzamanlı başladığı görülmektedir. Bu dönemden önce Batı denilen yer, genelde Müslümanlar, özelde Osmanlı için "Kendisinden güneşli İslam dünyasının öğreneceği hiçbir şey olmayan ve pek az korkacağı bir dışbarbarlık ve imansızlık karanlık”tan başka bir şey değildir (Lewis 1984, 35).Türk siyasi düşüncesinde Batı algısının en köklü kırılma noktalarından birini,tarihe Gülhane Hatt-ı Hümayunu olarak geçen Tanzimat Fermanı oluşturmaktadır. Tanzimat'la birlikte “Osmanlı İmparatorluğu kendisini Batı'dan üstün görme prensibine veda etmiştir” (Tunaya2010, 31).Tanzimat'a imza atan üç Paşa'nın (Mustafa Reşit, Ali ve Fuat Paşalar) Batıcılık konusunda hayli kuşkulu bir tutum içindeki devletin standartlarını bir başka noktaya taşıdığı, ödünsüz bir Batıcı olarak bilinen Mustafa Reşit Paşa'nın “medeniyet yolu” olarak nitelediği Batıcılığı ülkenin kurtuluşu olarak gördüğü bilinmektedir (Mardin 1996, 133).

Tanzimat Batıcılığı'na tepkinin bir ürünü olan Yeni Osmanlılar'ın Batı hakkındaki görüşleri bugün düşünce hayatındaki yansımaları açısından önemlidir. Baskın Oran, arzusunun odak noktasında "Batı gibi olmanın" yattığını öne sürdüğü Kemalist milliyetçiliğin, Tanzimat Batıcılığına tepkinin ürünü olan ve "Batı'ya teslimiyeti reddeden bir Batıcılık" olarak görünen Yeni Osmanlı düşüncesi tarafından hazırlandığını savunmaktadır (1999, 51). Bu noktada vurgulanması gereken, Osmanlı aydınlarının - Yeni Osmanlılar ve takiben Jön Türkler - Batı düşüncesinin epistemolojisinden çok siyaset öğretisi üzerine yoğunlaştıkları gerçeğidir. Osmanlı aydınının pozitivizmle meşguliyeti de bu sınırlar dahilindedir. Yani, Batı fikrini bu dönemde "geleceği parlak görünmeyen bir İmparatorluğun kurtarılması için ona bir nizam verme çabası" olarak değerlendirmek mümkündür (Özlem 2002, 458).

Türkiye'de ulusal kimlik inşasında derin izler bırakan Ziya Gökalp'in medeniyet ve Batı kavramına getirdiği açıklamalar, Kemalizm ve Cumhuriyet'indüşünsel temellerini anlayabilmek için son derece önemli niteliktedir. Şapolyo'ya göre Atatürk, "Duygularımın babası Namık Kemal” derken "fikirlerinin babası" olarak Ziya Gökalp'i göstermektedir (akt. Turan 1982 18) Gökalp'in Batı hakkındaki görüşleri, ünlü hars (kültür) ve medeniyet ayrımına dayanmaktadır. Hayli karmaşık görünen Gökalp terminolojisine göre hars, bir milletin "kıymet hükümleri” anlamına gelmektedir. Dolayısıyla Gökalp'in görüşüne göre, “(...)Batılılaşma, Avrupa'da bulunan medeniyet deposundan şeyler ve yöntemler almaktır. Asıl mesele Avrupa'dan hars almamaktır” (Berkes 2002, 93).

Osmanlı Batılılaşması ve Batı algısı ile erken Cumhuriyet dönemi Batı algısının arasındaki temel farkın liderden yani Atatürk’ten kaynaklandığını söylemek mümkündür. “Atatürk’te Batıyı alış, Osmanlı'nın tersine eklektik ve bölük pörçük değil, sistematik ve bütüncüldür” (Oran 1999, 264). Bu anlamda Atatürk’ün, fikirlerinin babası olarak gösterdiği Ziya Gökalp’ten özellikle 1926 sonrası ciddi ölçüde farklılaştığı anlaşılmaktadır. Erken Cumhuriyet dönemi fikriyatında Batı, hars ve medeniyet olarak ayrılmamakta, Hamdullah Suphi’nin dediği gibi medeniyetle birlikte harsın girişine gümrükte sınır konulamayacağı görüşü benimsenmektedir. Bir diğer önemli farklılık da Osmanlı'nın tersine Atatürk'ün Batı'yı bir amaç olarak almasıdır. Atatürk’e göre Batı, çağdaş uygarlıkla özdeştir ve ona karşı durmak diye bir şey yoktur (Oran 1999, 265). Tunaya ise, Cumhuriyet dönemi Batı fikrinin oluşumunda temel kaygıyı "Medeni bir toplum haline gelmek" olarak açıklamaktadır $(2010,137)$.

Erken Cumhuriyet dönemi Batı algısını yöneten bir diğer önemli motivasyon da Cumhuriyet elitinin Batı tarafından algılanma biçimini fazlasıyla önemsemesidir. Türkiye'den dışarıya yansımakta olan, "Batılılaşmaya çalışan ama diktatörlükle yönetilen ülke" görüntüsü özellikle Atatürk’ü rahatsız etmiştir. Serbest Cumhuriyet Fırkası denemesi, Türkiye'nin dış dünyaya karşı "Demokrat devletler" arasında yer aldığını gösterme amacını da içermektedir (Koçak 2006, 35-37).

Çok partili hayata geçiş ve Demokrat Parti'nin (DP) iktidara gelişiyle birlikte Türkiye'de Batı'ya bakışta, özellikle Amerika'ya ilişkin algıda belirgin bir değişim olmuştur. DP'li Cumhurbaşkanı Celal Bayar'ın Türkiye'yi 'Küçük Amerika” yapacağ1 vaadi (Bayar1999, 104), DP’nin “Her mahallede bir milyoner” gibi sloganlarıyla birleşince Türkiye toplumu için müreffeh, medeni bir Amerika - Batı - tablosu ortaya çıkmaktadır. Öte yandan, ekonomi politik olarak Batı yandaşı, kültürel olarak Batı karşıtı bir popüler muhafazakâr dil, siyaset alanını biçimlendirmeye başlamıştır. Yüksel Taşkın'a göre Kemalizm'den “Kültüralizm”iöğrenen milliyetçi muhafazakârlar, söylemlerinin kurucu bir bileşenini,Batılılaşma hareketinin Türkiye halkını köklerinden kopardığı tezi üzerine inşa etmiştir. Temel bölünme, "sessiz muhafazakâr/Müslüman millet” ile karşılarında fazlasıyla güçlü ve etkin "Batıcı azınlık" olarak iki kesim üzerine inşa edilmiştir (Taşkın 2013a, 88). DP hükümeti tarafindan örtülü ödenekten maaşa bağlanarak desteklenen Necip Fazıl, Batı'nın "tılsımlı bir umacı" halinden çıkarılmasını isterken, Büyük Doğu imzalı "alternatif hükümet programında” ,"Bu âlem, (Garp y.n.) sadece Rönesans’tan beri aklın fetih haklarını kullanmış ve eşyayı ustalıkla teşhir etmiş bir müsbet bilgiler farikasından ibaret bilinecek ve keşiflerine hâkim ruhtan mahrum diye bellenecektir (...)" demektedir (Büyük Doğu, 1956).

Türkiye'nin Batı algısında kritik kopuş, 12 Eylül 1980 darbesi sonrası yaşanmıştır. 1980’lere kadar Kemalist Batıcılık anlayışı pek tartışma konusu yapılmadan "muasır medeniyet seviyesi” adıyla resmi ideolojinin içine eklemlenirken, Batı fikrine ontolojik karşıtlığın devlet aklında yer edinmesi 12 Eylül rejimiyle mümkün olabilmiştir. Belge, bu durumu "Mustafa Kemal'in tavrından, Ziya Gökalp'in tavrına geçilmesi” olarak yorumlamaktadır (2002, 55). Darbenin Lideri Orgeneral Kenan Evren, hemen tüm konuşmalarında tüm olumsuzlukları "iç ve dış mihraklarla" ilişkilendirmekte, Türkiye'de komünist parti faaliyetlerinin yasak olmasını eleştiren Avrupa basınına “Avrupa'nın bazı ülkelerinde faşist parti yoktur ve yasaktır. Biz onlara söylüyor muyuz niye faşist parti yok diye?” şeklinde dikkat çekici yanitlar vermektedir (akt. Belge 2002, 55). 
Sonraki süreçte Batı fikrinin üretiminde, Kürt meselesi ve Avrupa Birliği adaylık süreci temel belirleyiciler olarak öne çıkmaktadır. Ayrıca, 1990'larda yükselişe geçen Refah Partisi, milliyetçi/muhafazakâr düşüncedeki "Şeytani Batı" algısını popüler siyaset dilinde - halk katında - canlı tutmaktadır. Erbakan, şöyle demektedir:

"Batı buraya ne getirecek? Hilekârlık, homoseksüellik getirecek. Erkeğin erkekle evlenmesini getirecek. Bu yüce gaye değil, cüce gayedir. Bre cüceler. Sizi gidi masonik kafalar, sizi gidi gâvur âşıkları sizi.”(Milliyet, 6 Temmuz 1995).

Erbakan, bu konuşmayı yaptıktan 4 yıl sonra partisi kapatılıp 4 yıl 26 günlük hapis cezasına çarptırılmasının ardından cezasının durdurulması için Avrupa İnsan Hakları Mahkemesi'ne başvururken, görüşlerinin değil, Avrupa'nın değiştiğini, artık $\mathrm{AB}$ üyeliğini desteklediğini söylemektedir (Milliyet, 26 Temmuz 1999). Yine de milliyetçi muhafazakâr siyasi düşüncenin Batı konusundaki ezberini bozan, 2002'de AK Parti'nin iktidara gelmesi olmuştur. AK Parti'nin AB'ye tam üyelik bağlamında giriştiği reformlar, Türkiye'de siyasal kutuplaşmanın, milliyetçilik ve statükoculuk üzerinden belirlenmesini beraberinde getirmiştir. Kemalizm ve resmi ideolojinin, siyaset yapma biçimine blokajı aşmak için - bir zamanlar DP ve ANAP'ın yaptığı gibi - uluslararası sisteme entegrasyonu gerekli görenAK Parti (Taşkın 2013b, 35), oy aldığı seçmenler nezdinde de Batı algısını yeniden şekillendirmiştir. Bu dönemi, muhafazakâr popülizmin hars-medeniyet ve yerli-yabancı dikotomisine dayanan geleneksel söyleminden bir kopuş olarak görmek mümkündür. Ancak, 2008 sonrasında Genel Başkanı Erdoğanbaşta olmak üzere parti sözcülerinin söyleminden anlaşılan, "kadim" hars-medeniyet ve yerli-yabancı ayrımının, Batı algısını üretmekte yeniden ön plana çıkmış olduğudur. Söz gelimi Başbakan Erdoğan 2008'de yurtdışına burslu gönderilecek öğrencilere hitap ederken "Biz Batının ilmini sanatını almadık. Maalesef değerlerimize ters düşen ahlaksızlıklarını aldık. Biz Batının ilmini sanatını almakta bir yarışa girmeliyiz"(Milliyet, 24 Ocak 2008)diyerek Kemalist Batıcılık anlayışının bütüncülüğünü eleştirmektedir.

Türkiye'de Batı imgesinin evrimini, Garbiyatçılık perspektifinden değerlendirecek olursak şunları söylemek mümkündür:

Garbiyatçılığın hem üretici hem tüketicisi olma haliyle ve meşhur "Batı ve Doğu arasındaki köprü" olma metaforunun sağladığı imkânlarla birlikte Türkiye, kendi Doğusu'nu Batı'dan, Batısı'nı ise Doğu'dan kurabilmek gibi bir imkâna sahiptir. Bu durum nedeniyle Türkiye'de Batı fikri, Şarkiyatçılık ve Garbiyatçılık arasında ikircikli (ambivalent) bir algıya sahiptir. Doğu ve Batı'yı birleştiren bir köprü olma olanağı, Türkiye'ye hem oraya hem buraya, ya da bir oraya bir buraya ait olabilme fırsatı vermekte; bunun mümkün kıldıkları, özellikle iktidarın inşası ve meşrulaş̧ırılması bağlamında Garbiyatçı söylemin manevra alanı için sıradışı bir repertuar sunmaktadır. Ahıska'nın söz ettiği gibi "Köprü, birleştirici olduğu kadar ayırıcıdır. (...) Doğu-Batı arasına sıkışmış ülkenin 'yalnızlığı' ve 'yabancılığı'nı, Türkiye'de iktidar hegemonyasının metaforik yapıtaşları" olarak adlandırmak mümkündür (2009, 1039).

Modernleşme ile arasındaki zaman aralığı yüzünden Batı hakkında karmaşık görünümlerin ortaya çıkabildiği Türkiye'nin, Garbiyatçılık açısından sıradışı bir birikime sahip olduğunu söylemek mümkündür. Kolonyalizm sürecinde Batı hegemonyası ile doğrudan temas etmiş, ya da Türkiye gibi periferal bir modernleşme projesi aracılığıyla Batı fikri ile tanışmış toplumların ürettiği Batı algısının nitelikleri, Batı'yı anlamaktan çok, kendileri üzerine öz-düşünümsel bir alg1 geliştirmek açısından önemlidir. Tarihsel olarak Batı'ya bakış, Türkiye'nin kendine bakışını özetlemektedir. Dolayısıyla bu bağlamda yapılacak çalışmaların, toplumsal kimliğin katmanlarını açımlamak konusunda değerli olduğunu söylemek mümkündür. Özellikle Türkiye'nin de Batı-dışı, periferal modernleşme etkisi altında, Batı'yı kendisi için "kurucu-öteki" olarak benimsemiş bir tarihsel geçmişi olduğu dikkate alındığında, Türkiye tarihi ve toplumsal kodlarını tanımlamada Garbiyatçılık kavramının anlamlı bir perspektif önerebileceği düşünülmektedir.

Ahıska, Garbiyatçılığı "Hem Batıcılık hem Batı karşıtlığı anlamında oluşturulan tepkileri" de kapsayan bir mercekten görürken “(...) anlatıların ve pratiklerin anlamlandırıldığı hegemonik bir üst dile” $(2009,1052)$ işaret etmektedir. Bu üst dil, "bize özgü" ve "yabancı" arasında bir ayrım yapmaya yaramakta; arzu, nefret vb. birçok karmaşık duyguyla oluşturulan bir "toplumsal gramer"e dayanmaktadır. Garbiyatçılık kavramını, Türk ulusal kimliğinde Batı'nın zamansal/uzamsal imgelemde ortaya çıkma biçimini kavramsallaştırmak için öneren Ahıska, hem modernleşmeci elitlerin hem karşıtlarının bir iktidar söylemi olarak modernleşme ve Batı görünümleri ürettiğini vurgulamaktadır. Ahıska'nın Garbiyatçılığın temel kaynaklarından biri olarak modernleşme sürecindeki zaman aralı̆ğ (time lag) ve bunun yarattı̆̆ı "treni yakalama kaygısını" gördüğünü söyleyebiliriz. Bu temelde Garbiyatçılığı, Batı karşıtı ya da yandaşı söylemler gibi kategorilerde değil, “(...) iktidarı elinde bulunduranların pragmatik çıkarları çerçevesinde hegemonyalarını güçlendirmek ve müzakere etmek üzere "Batı" fikrini üretmeleri ve tüketmelerini anlatan bir sosyal imgelem sahası..." olarak ele almak mümkündür (Ahıska 2003, 366).

Bu çalışmada, Garbiyatçılık kavramı, Doğulu'nun gözündeki Batı imgesi gibi masum bir içerikle sınırlı tutulmayacaktır. Garbiyatçılık, Ahıska'nın da önerdiği gibi, Batı imgesini de içine alan "Batı fikrinin iktidar sağlayan bir sosyal imgelem sahası" olaraküretilmesi biçiminde ele alınacaktır. 


\section{TRT Haberleri’nde Garbiyatçılık}

$\mathrm{Bu}$ çalışma, Türkiye'de televizyon haberlerini inceleyerek Garbiyatçılık fikrinin kitle iletişim metnine dahil oluşu hakkında, bir dizi çerçeve önermeyi amaçlamaktadır. Çalışmanın temel problematiği, Batı ve Doğu kavramlarının coğrafi bir ayrımdan çok bir sınıflama ve kategorizasyon sistematiği içerdiği; televizyon haberlerinin bu ayrımın altını çeşitli boyutlarda çizerek, Batı ve Doğu kavramlarını sosyal olarak inşa ettiği düşüncesidir.

\subsection{Araştırma Evreni ve Örneklem}

$\mathrm{Bu}$ araştırmanın evreni televizyon haberleridir. Ancak, sosyal bilimlerde yapılan pek çok çalışma, araştırma evreninin bütünü değil, sınırları belirli bir örneklemin incelenmesine dayanmaktadır. Kitle iletişim araçlarına yönelik analizlerin çoğunda çok aşamalı bir örneklem belirlendiğini söylemek mümkündür (Atabek 2007, 11). Bu çalışmada, sorunsal ve amaçlar da dikkate alınarak, araştırma evreninden "amaçsal örneklem" alınmıştır. Türkiye'nin Batı ile kurduğu tarihsel ilişkiler ve devletin bu ilişkilerdeki belirleyici unsur olması dikkate değer bulunarak, devlete bağlı "özerk” yayın teşkilatı Türkiye Radyo Televizyon Kurumu (TRT) bünyesindeki TRT Haber kanalı iletişim kaynağı olarak seçilmiştir. $A B D$ ve $A B$ ile karşılıklı ziyaretlerin, Suriye'deki iç savaşa, Mısır'daki darbe sürecine ilişkin haberlerin yoğunluk kazandığı, 1 Nisan 2013'ten 1 Ağustos 2013'e kadar olan 4 aylık dönemdeki toplam 86 saat 42 dakika 7 saniyelik Ana Haber Bülteni kaydedilerek incelenmiştir. İletişim kaynağı ve dökümanlar seçildikten sonra araştırma amaçlarına uygun olarak bir kısıtlamaya gidilmiştir (Holsti 1969). Haber bülteni içinde Batı kavramı ile herhangi bir şekilde ilişkili haberler örnekleme dahil edilirken; araştırma amaçlarının tamamen dışında kalan konulardaki (Bir kasabadaki uçurtma festivalini anlatan haberler gibi) haberler, örnekleme alınmamıştır. Bu kısıtlama ile birlikte araştırma amaçlarına uygun olan haberlerin 9 saat 28 dakika 18 saniyelik bölümü örnekleme dâhil edilirken, geri kalan haberler örneklem dişında bırakılmıştır.

\subsection{Analiz Metodu}

$\mathrm{Bu}$ araştırma, bir iletişim metni içeriğinin çözümlemesine yöneliktir. Bu nedenle, araştırma yöntemi olarak içerik çözümlemesi seçilmiştir. Eldeki verilerin nicelleştirilmesi frekans analizi tekniği ile gerçekleştirilmiştir. Bulguların yorumlanmasında ise haberde çerçeveleme yaklaşımından yararlanılmıştır.

Sosyal bilimlerde, nitel çıkarsamalar gerektiren araştırmaların nicel verilerden yararlanması önemli bir tartışma konusudur. Berelson'a göre "İçerik çözümlemesi, iletişimin açık/aşikâr (manifest) içeriğinin nesnel, sistematik ve nicel olarak betimlenmesine yönelik bir araștırma tekniğidir” (akt. Atabek 2007, 4). Ancak bu konuda görüş birliği olduğunu söylemek zordur. Söz gelimi Thomas, açık/aşikâr içerik ile kapalı/örtük içerik anlamları arasında sınırların kolayca çizilemeyeceğini vurgulamaktadır(Atabek 2007, 4). Bilgin’e göre de içerik çözümlemesi, "Söylemin görünen, kolayca yakalanan, sergilenmiş ve ilk bakışta algılanan içeriği yerine, gizil, üstü örtülü içeriğini ortaya çıkarmayı sağlamaktadır" (2006, 1). İçerik çözümlemesinin sadece nicel verilerden ibaret olup olmadığ 1 da tartışılmaktadır. Yumlu, içerik çözümlemesinde artık niceliksel ve niteliksel yaklaşımların birbirlerini tamamlayıcı olarak kullanıldığına dikkat çekmektedir (1994, 76). İçerik analizi, "kantitatif doğası, metinsel bütünlükleri parçalaması, pozitivist nesnellik nosyonu, bir anlam teorisinden yoksunluğu(...) (Negrine 1998, 91)"gibi gerekçelerle eleştirilse de, günümüzde medya çalışmalarında en çok kullanılan yöntemlerden biridir. Bu araştırmada benimsenen içerik çözümlemesinde hem nicel hem nitel verilerin ele alınmasına olanak tanınmıştır. Örneğin frekans analizi temelde nicelleştirmeye dayansa da, sayılacak tematik birimlerin belirlenmesi, çerçevelerin oluşturulmasıve yorumlanması nitel bir süreç içermektedir.

Elde edilen veriler, birbirini tamamlayan iki ayrı bölümde analiz edilmiştir. Bu bölümler, "çerçeveleme" yaklaşımından yola çıkılarak oluşturulmuştur. Çerçeveler; bireylerin, konu, olay ve başlıkları, yerleştirme, algılama, tanımlama ve etiketlemelerine yarayan yorum şemalarıdır. Olayların anlatı akışını basitleştirir, öncelikli hale getirir ve yapılandırır (Goffman1986, 21). Bir iletişim metnindeki çerçeveleme ise herşeyden öncebir "seçme ve belirginleştirme" sürecidir. Bir konunun metinde daha görünür ve vurgulanır hale getirilmesi çerçeve olarak değerlendirilmiştir (Entman 1993, 52).Bu çalışmada iletişim metninin çerçevesi, "Sembol oluşturucuların rutin olarak söylem oluşturmalarını sağlayan, sürekliliği olan biliş, yorum, temsil, seçim, vurgu ve dişlama kalıplart...(Gittlin 1980, 7)” olarak görülmüştür.

Araştırmanın ilk aşamasında, haber metninin makro niteliklerine odaklanılmıştır. Bu aşamada, haber metni, daha önce çeşitli iletişim araştırmalarında kullanılan Genel Çerçeveler (Generic Frames) temelinde analiz edilmiştir. Genel Çerçeveler'in, haber metninin makro niteliklerini çözümleme konusunda farklı zaman ve kültürel kodlarda da sonuç verici olduğu vurgulanmaktadır (DeVreese 2001, 108).

Araştırmanın sonraki aşamasında ise, metnin içeriğindeki Garbiyatçı anlatının çıkarsanması (interference) için De Vreese'nin önerdiği "konu-odaklı çerçeveleme" (issue-specif framing) yöntemi kullanılmıştır. De Vreese'ye göre konuodaklı çerçeveler, genel çerçevelerden daha spesifik bir şekilde, belirli konuları detaylı ve tüm özellikleriyle ele almayı sağlamaktadır $(2005,54)$. Ancak sağladığı detay ve konuya odaklı hassasiyet, teori oluşturmada genelleme yapma, karşılaştırma güçlükleri yaratmaktadır. Bu araştırmada konu odaklı çerçeveleme çözümlemesine yönelmek, medya 
metninin içeriğindeki Garbiyatçı anlatının deşifre edilmesi ve çalışmanın özgünlüğü açısından zorunlu görünmektedir. $\mathrm{Bu}$ amaçla, çalışmanın teorik kısmında anlatılan Türk siyasi düşüncesindeki Batı kavramının temel niteliklerinden yola çıkılarak, örneklem üzerinde yapılan ön inceleme sonucu bu çalışmaya özgü çerçeveler oluşturulmuştur. Bu çerçeveler, çalışma öncesi tasarlanan başlıkları içerdiği gibi, kimi zaman iletişim metninin ortaya koyduğu yeni öğelerin değerlendirilmesiyle sonradan belirlenmiştir.

\section{Çözümleme Birimi}

İçerik çözümlemesinde sayılan birim, çözümleme birimi anlamına gelmektedir. Verilerin nicelleştirilmesi için en uygun birimler olarak fiziksel ve sözdizimsel birimler öne çıkmaktadır (Atabek 2007, 13). Fiziksel birimlerin içine gazeteler için sayfa-haber sayısı, sütun-santim ölçüsü gibi parametrelerin yanı sıra görsel ve işitsel iletişim metnindeki süre ölçümü de girmektedir. Ancak içerik çözümlemesinde nitel bulgulara erişmek için tematik birimler de kullanılmaktadır (Atabek 2007, 14). Bu araştırmada, medya metni, öncelikle tematik birimlere (kategorilere), sonra ise fiziksel birimlere bölünmüştür. Görüntüler ise değerlendirilmeye alınmamıştır. Tematik birimleme aşamasında, araştırmanın dayandığı çerçeveleme yaklaşımına uygun olarak medya içeriği, mesajın anlamına yönelik olarak ayrılmıştır. Tematik birimleme işleminin ardından, diğerinden kavramsal bakımdan farklılaşan her birimin iletişim içeriğindeki miktarı, süre olarak saniye cinsinden ölçülmüştür. Bu sürecin sonucunda elde edilen nicel ve nitel bulgular kavramsal çerçeve doğrultusunda yorumlanmıştır.

\subsection{Araştırmanın Bulguları}

İlk olarak çözümlemede ortaya çıkan bulguların yorumlanmasına yardımcı olacak bazı nicel verilerin ortaya konulması amaçlanmaktadır. Bu yolla, TRT Haber'de yayınlanan haberlerin makro niteliklerinin vurgulanması mümkün olabilecektir. Araştırmanın yapıldığı 1 Nisan ile 1 Ağustos 2013 tarihleri arasında TRT Haber Ana Haber Bülteni’nin toplam süresi 86 saat 42 dakika 7 saniye (312 bin 127 saniye) olarak ölçülmüştür. Bu süredeki haberlerin yüzde 10.92'si, yani 9 saat 18 dakika 18 saniyesi (34 bin 98 saniye) doğrudan Batı kavramı ile ilişkilidir.

TABLO 1: Haber Bültenleri'nde Batı Kavramıyla İlişkili Haberlerin Oranı

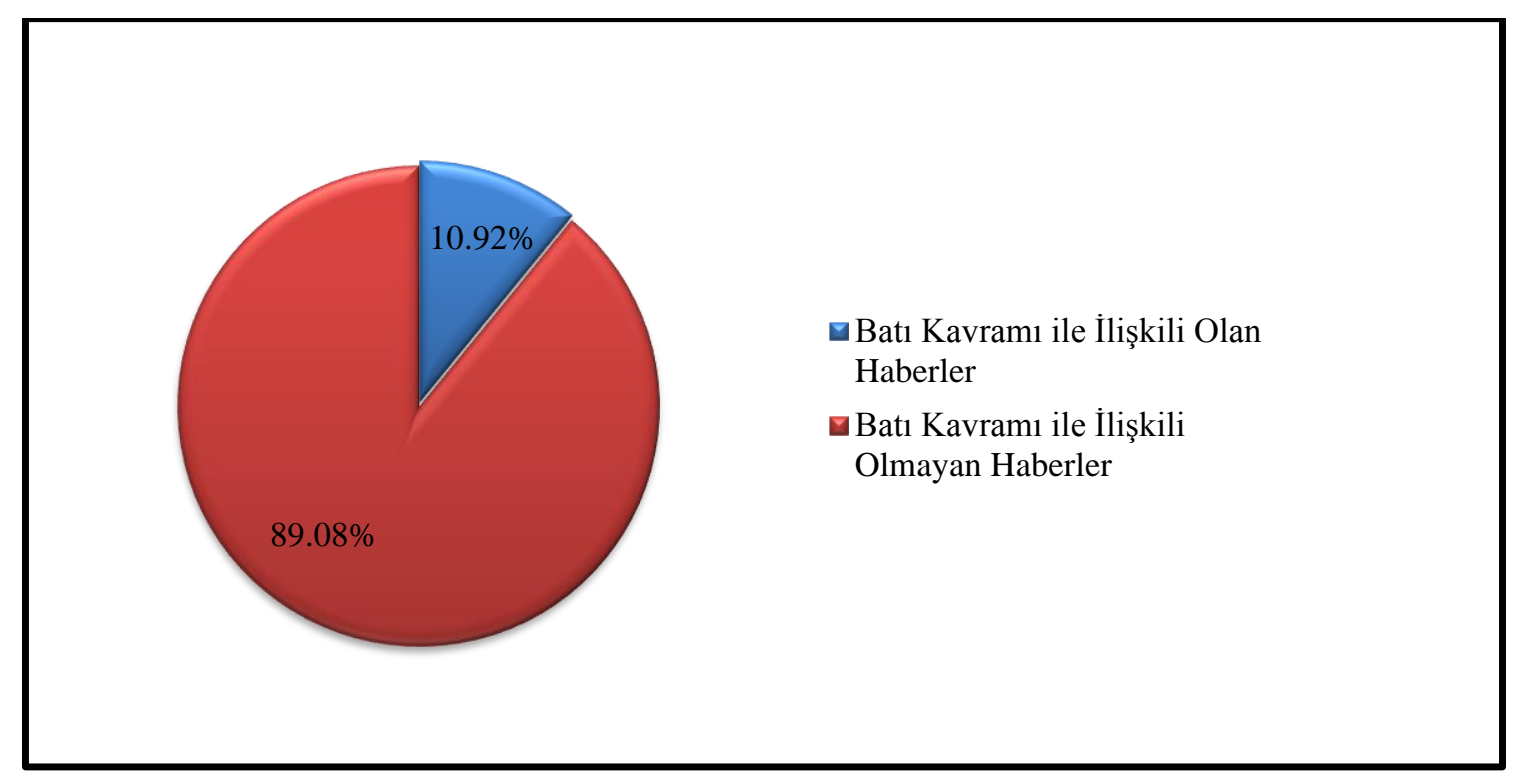

Batı kavramı kodlanırken, coğrafi bir ayrımdan öte "metindekisiyasal ve kültürel bir anlam” olarak düşünülmüştür. Dolayısıyla, Avrupa Birliği (AB) ülkeleri, Norveç, İsviçre ve Amerika Birleşik Devletleri’nin (ABD) yanı sıra Rusya ve İsrail gibi böylesi bir kategorizasyonda siyasi olarak yeri tartışmalı pozisyondaki ülkelerle ilgili haberler de Batı kategorisine dâhil edilmiştir.

TRT Haber bültenlerinde Batı ile ilgili haberlerin ağırlığı, toplam dış haber süresi dikkate alındığında anlamlı bir yorumu mümkün kılmaktadır. İncelenen dönem içinde yayınlanan haberlerin yüzde 18.22'sini dış haberler oluşturmaktadır. Batı ile ilgili yayınlanan haberler, total haberlerin yüzde 10.92'sini oluşturmakla birlikte tüm dış haberlerin yarısından fazlası, yani yüzde 59.94'ü Batı hakkındadır. Geri kalan dış kaynaklı haberlerin yüzde 28'i Ortadoğu ülkeleri, yüzde 12'si dünyanın geri kalanıyla ilgilidir. 
TABLO 2: Tüm Haberler Arasında Batı Kavramı ile İlişkili Haberlerin Oranı

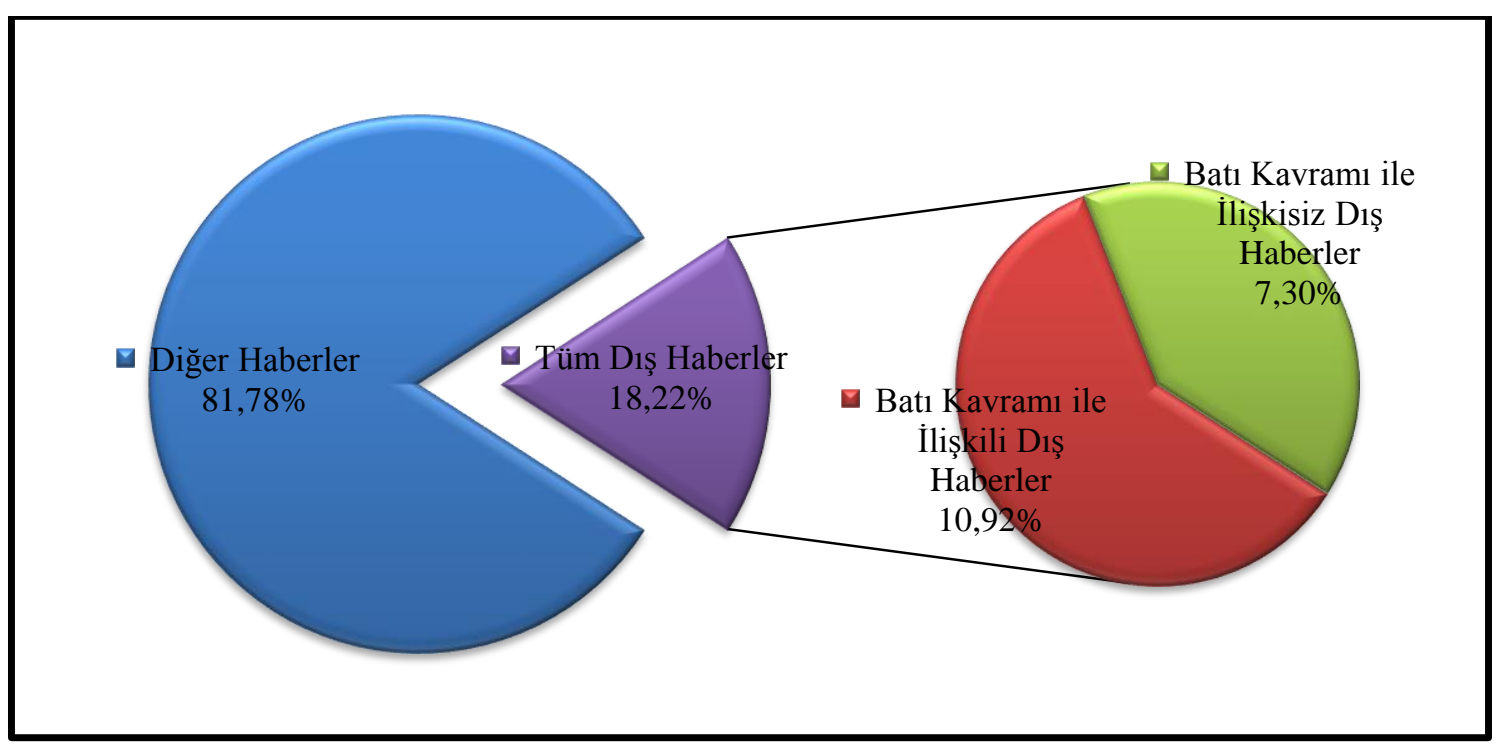

Bu rakamlar, Batı'nın TRT'de oldukça geniş şekilde temsil edilen bir figür olduğunu göstermektedir. Osmanlı/Türk siyasi düşüncesinin 300 yıla yaklaşan modernleşme serüveni dikkate alındığında olumlu ya da olumsuz anlamda Batı'nın önemli bir referans noktası olmaya devam ettiği görülmektedir. Araştırmanın bundan sonraki aşamalarında, örneklemi, yani 4 aylık toplam bülten süresinin yüzde 10.92'sini oluşturan 9 saat 18 dakika 18 saniyelik Batı ile ilgili haberlerin nasıl çerçevelendiği tartışılacaktır.

\subsubsection{Genel Çerçeveler}

Çerçeveleme araştırmasının ilk bölümünde bulgular, daha önce yapılan çerçeveleme araştırmalarından ortaya konan genel çerçevelerden (generic frames) yola çıkılarak değerlendirilmiştir. Haber metinleri tematik ve epizodik, ahlaki ve teknikçerçevelerinin yanı sıra çerçeve sponsorları bağlamında da incelenmiştir. Bulgular ve yorumlar aşağıda yer almaktadır.

\section{Haberlerin Süreksiz (Episodik) ve Tematik Çerçevelenmesi}

Haberlerinsüreksiz olarak çerçevelenmesi, haber öyküsünün birbirinden ayrı oluşturulmuş, arka plan bilgisinden, derinlik ve çok katmanlılıktan yoksun olması şeklinde tanımlanabilir. Tematik çerçevelenmiş haberlerde ise, olaylar birbirinden kopuk gelişmeler olarak değil, bir ardalan bilgisi dahilinde çok boyutlu olarak aktarılmaktadır. Haberde ardalan ve bağlam sorununun doğrudan hikâyenin yapısını değiştirdiğini savunan Iyengar'ın çerçeveleme araştırmalarına göre, süreksiz çerçevelenen haberler; haber anlatısına konu olan olayları; bağlantısız, fragmante hikâyeler serisine, bağımsız etkinliklere veya vakalara indirgemektedir (1997). Buna karşın, tematik çerçevelenen haberlerde, anlatı, belirli bir bağlama oturtulmakta; zaman ve mekân sınırlamalarını aşma kapasitesi barındırmaktadır. Süreksiz çerçevelerde, "somut olay ve insan hikâyeleri" bağlamı baskınken (tecavüz sorununun salt bir tecavüz kurbanının hikâyesi bağlamında anlatılması gibi); tematik çerçevelerde daha genel ve soyut tanımlamalar (tecavüz sorununun kadın hakları ve patriarkal yapı bağlamıla sunulması gibi) kullanılmaktadır. Iyengar'a göre televizyon haberciliğinde süreksizçerçevelemenin en büyük sonucu, "politik konularda sorumluyu gizleme" etkisidir (1991, 2).Ancak, tematik çerçevelenmiş haberlerin hazırlaması daha uzun sürdüğü,derinlemesine yorumlar-analizler gerektirdiği; ayrıca bu tarzda bir haber üretiminin gazetecilik önyargısı üzerine suçlamalara daha açık olacağı gibi kaygılarla süreksiz çerçevelenmiş haberler tercih edilmektedir (Iyengar, 1991, 2).

Bu araştırmanın bulgularınagöre, TRT Haber'de Batı kavramı ile ilgili haberler yüzde 94.35 gibi oranla, süreksiz çerçevelenmiştir. Tematik çerçevelenen haberlerin oranı ise yüzde 5.65'tir. 
TABLO 3: Haberlerin Süreksiz(Episodic)-Tematik Çerçevelenmesi

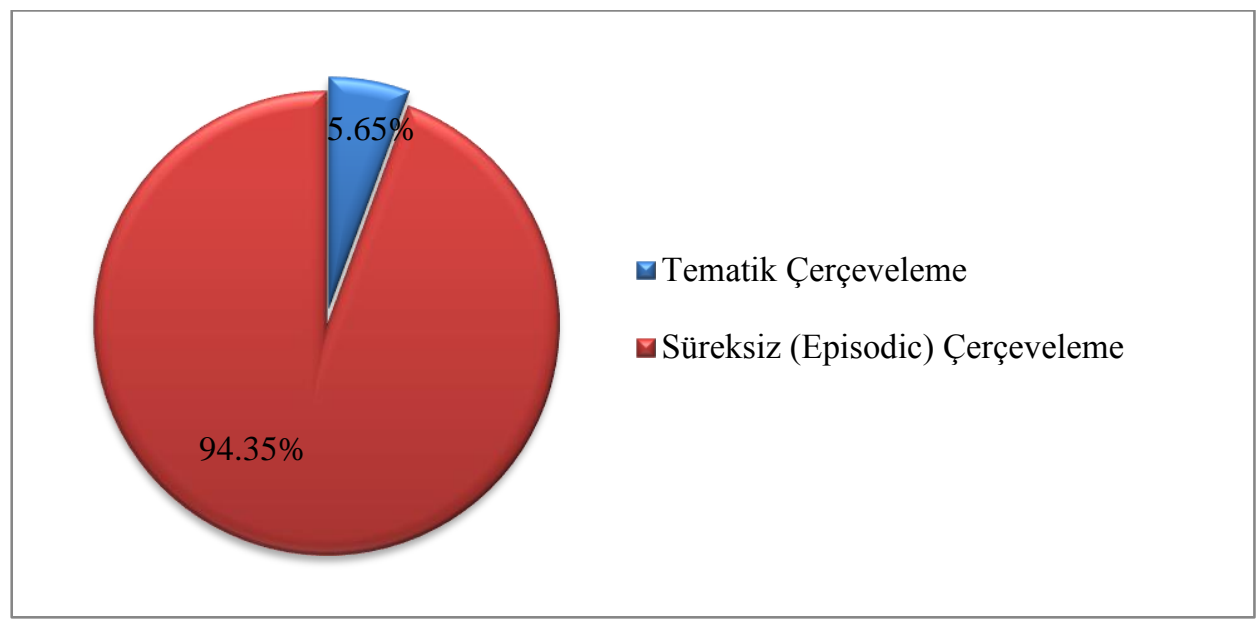

Araştırmada süreksiz çerçevelendiği şeklinde kodlanan haberler, neden-sonuç ilişkisi kurmanın mümkün olmadığ1, bağlam ve ardalan bilgisinden uzak haber metinlerini içermektedir. Mesela, incelenen dönemde 7 Haziran 2013 günü ABD Büyükelçiliği'nin, 13 Haziran 2013'te AB Parlamentosu'nun, 19 Haziran 2013'te ise Almanya Başbakanı Angela Merkel'in Türkiye'deki insan hakları ihlallerine yönelik eleştirilerine bültenlerde yer verilmemiş; ancak 8,14 ve 21 Haziran'da bu açıklamalara yanıt veren Türkiye'deki hükümet yetkililerinin demeçleri bültenlerde yer almıştır. Bu durum, haberler arasında bir nedensellik bağı kurmayı güçleştirmektedir. Süreksizçerçevelenen haberler, genelde bir haber aktörünün, mesela bir siyasetçinin konuşması ya da gelişen bir olayın aktarılması üzerine kuruludur. Bu nedenle haberler, çok büyük oranda kaynak söylemine bağımlı niteliktedir. Bulgulara göre TRT bültenlerindeki süreksiz çerçevelemenin ağırlığı, olaylar arasındaki neden sonuç ilişkisini engelleyerek, izleyici açısından bütüncül bir anlam oluşturmayı zorlaştırmaktadır.

\section{Çerçeve Sponsorları (Frame Sponsors)}

Haber çerçevelerinin oluşumu, sadece medya profesyonelinin denetiminde değildir. Van Gorp'un Çerçeve Sponsorları (Frame Sponsors) olarak sözünü ettiği haber kaynakları, baskı grupları, politikacılar kendi çerçevelerini etkin kılmak için bir mücadele içindedir $(2007,62)$. Haber öykülerindeki çerçevelerin “gücün mührü”nü taşıdığını belirten Entman'a göre bu çerçeveler, "Metne hâkim olmak için rekabet eden aktör veya çıkarların” kimliğini kaydetmektedirler (1993, 53). Araştırmanın bu aşamasında, TRT haberleri, kaynaklar ve haber eyleyeni (aktörü) bağlamında irdelenmiştir. TRT haberlerinde, hangi haber aktörlerinin etkin olduğu aşağıdaki tabloda (TABLO 4) gösterilmektedir:

TABLO 4: Haber Aktörlerine Göre Haberlerin Çerçevelenmesi

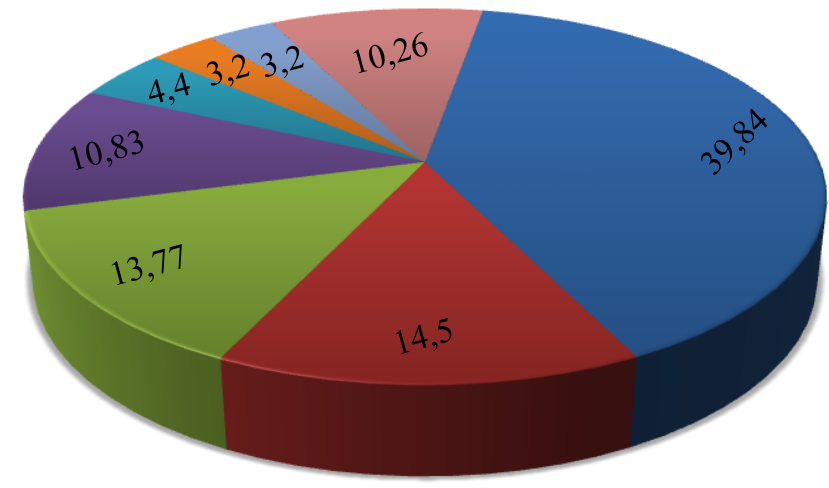

๑Başbakan

- Cumhurbaşkanı

๑T.C. Vatandaşları
๑Bakanlar Kurulu

๑İç Politik Aktörler

$\square$ Diğer
๑ Yabancı hükümetler

$\square$ Yabancı Basın 
TRT Haber'in incelenen döneminde önde gelen çerçeve sponsoru,yüzde 39.84'lük bir oranla Başbakan'dır. Bakanlar Kurulu, yüzde 14.50'lik payla en önemli ikinci haber aktörü durumundadır. Yabanc1 hükümetlerin temsilcilerinin haberlerde bir aktör olarak yer alışı yüzde 13.77'dir. Cumhurbaşkanı'nın yüzde 10.83'lük oranla dördüncü sırada yer aldığı gözlenirken, yüzde 4.4 ile Türkiye'deki siyasetçiler, Cumhurbaşkanı'nı izlemektedir. Yabancı basın ve Türk vatandaşlarının Batı ile ilgili haberlerde varlığı yüzde 3.2'lik bir düzeydedir. Yerli ve yabanc1 diplomatların, yerli uzmanların haber aktörü olarak ağırlıkları ihmal edilebilir düzeyde kalmıştır.

Bu bulgulara göre, TRT Haberleri'nin en etkili çerçeve sponsorunun siyasi iktidar olduğu gözlenmektedir. Batı'yı tanımlamada, Başbakan ve Bakanlar Kurulu üyelerinin toplam yüzde 54.34'lük bir oranla hegemonik bir ağırlığa sahip olduğunu söylemek mümkündür. Devlet televizyonun haber bültenleri içinde siyasi iktidarın bu ağırlığı, Batı kavramı ile ilgili çerçevelerin oluşumuna hayli aktif bir katkıda bulunduğunu göstermektedir.

\subsubsection{Konu Odaklı Çerçevelemeler}

Bu bölümde TRT bültenlerindeki Garbiyatçı anlatının hangi çerçeve ve kategoriler aracılığıyla inşa edildiğinin ortaya çıkarılması amaçlanmaktadır. Veriler, De Vreese'nin önerdiği konu-odaklı çerçeveleme (issue-specific framing)yaklaşımı temelinde çözümlenecektir. Örneklem üzerinde yapılan ön inceleme sonucunda, haber anlatısının Batı fikrine ilişkin barındırdığı iki temel çerçevenin "yerlilik" ve "yabancılık” tanımı yapmaya yönelik olduğu gözlenmiştir. Bu nedenle TRT haberlerinde Batı fikrinin üretimi, “OntolojikKarşıtlık” ve "Epistemolojik Kuruculuk”, olarak iki ana çerçevede analiz edilecektir. $\mathrm{Bu}$ iki ana çerçeve, kendilerini oluşturan alt kategoriler içinde yorumlanacaktır.

$\mathrm{Bu}$ araştırmaya özgü olarak belirlenen konu-odaklı iki çerçevelemenin kesişme ve ayrışma noktaları, sosyal psikolojideki sosyal kimlik ve sosyal kategorizasyon kavramlarıyla ilintilidir. Sosyal kimlik kuramına göre insanlar, çevrelerini düzenlemek, sosyal dünyada kendi yerlerini belirlemek ve tanımlamak için kategorizasyon sürecini kullanırlar. Bu yolla, çevrenin karmaşıklığını azaltıp, dünyayı daha kolay öngörebilecekleri bir yer haline getirirler. Bilişsel bir süreç olarak görebileceğimiz sosyal kategorizasyon sürecinin, Tajfel'e göre iki temel işlevi bulunmaktadır: Kategorizasyon, ilk olarak sosyal çevrenin anlaşılması için yardımcı olur ve yol gösterir; ikinci olarak ise bireyin belirli bir toplumda özel bir yer oluşturmasında ve kendini tanımlamasında rol oynar (Tajfel, 1978).Kitle iletişim araçlarının bu bilişsel sürece, her bir kategori içerisinde algılanan benzerlikleri ya da farklılıkları vurgulama yolu ile katkıda bulunduğu söylenebilir. Haberleri çözümlemede kullanılan Ontolojik Karşıtlık Çerçevesi, bu çalışmada önerilen Garbiyatçılık kavramına paralel olarak, yani iktidarların kurucusu olduğu pragmatik bir Batı imgesinin üretimine katkıda bulunan haberlere karşılık gelmektedir. Bu çerçeve dâhilinde, Batı fikrinin kategorize edildiği ve sistematik bir sınıflandırmaya dayanarak inşa edildiği öne sürülecektir. Epistemolojik Kuruculuk Çerçevesi ise, Batı fikrinin muhayyel bir "biz" tanımlamaya yönelik yapısına içermektedir. Yapılan çözümlemede her iki çerçeve ve alt kategorileri ölçüldüğünde ulaşılan bulgular şu şekildedir:

TABLO 5: Haberlerin Konu Odaklı Çerçevelenmesi

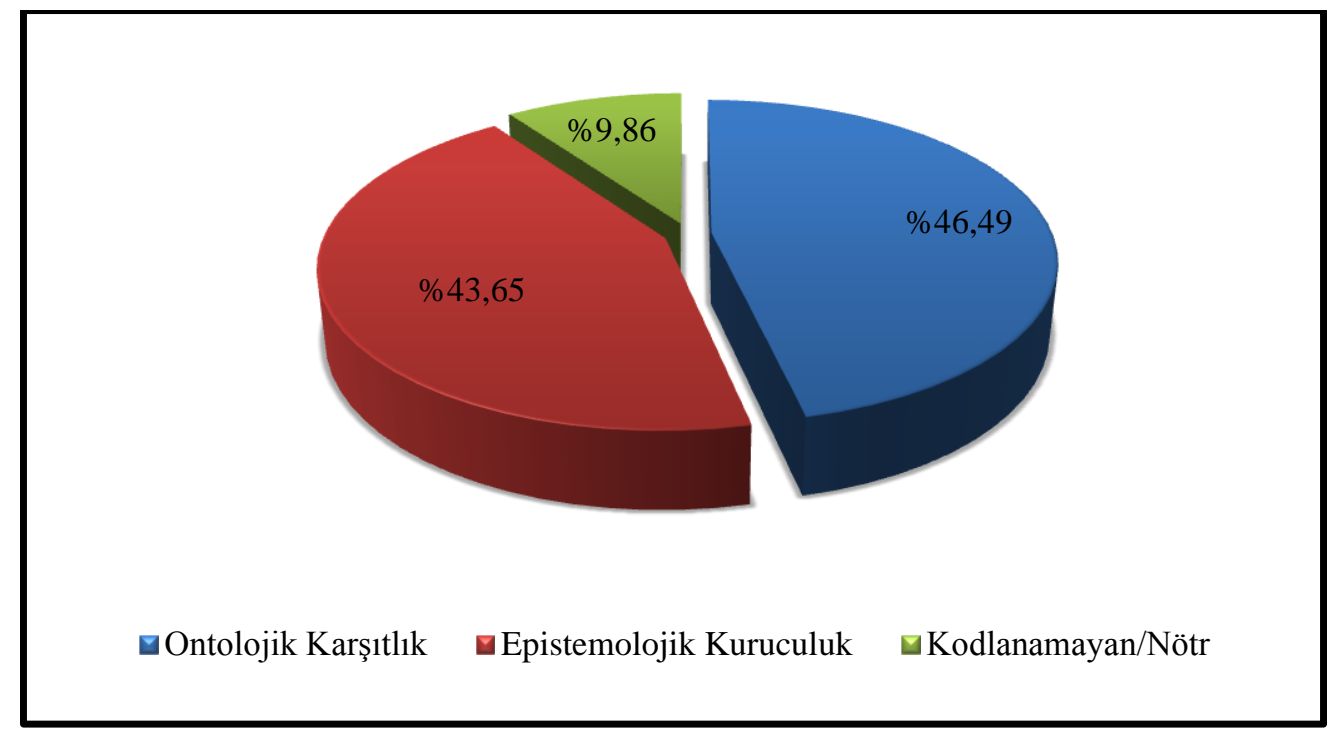

Araştırma bulgularına göre haberlerde Batı fikrinin Ontolojik Karşıtlık ve Epistemolojik Kuruculuk olarak çerçevelenmesinin oldukça yakın değerler içerdiği görülmektedir. Örneklem dahilindeki haberlerin süresinin yüzde 46.49'u Ontolojik Karşıtlık Çerçevesi içinde yer alırken, yüzde 43.66'sı Epistemolojik Kuruculuk Çerçevesi'ne yönelik 
görünmektedir. Verilerin yüzde 9.85 'i ise araştırma amaçları ve hali hazırdaki çerçeve ve kategorilere göre anlamlı bir sonuç içermediğinden kodlanamamıştır.

\section{Ontolojik Karşıtlık Çerçevesi}

Yapılan çözümlemede, örneklemde yer alan haberlerin yüzde 46.49'unu oluşturan Ontolojik Karşıtllk Çerçevesi, üç kategori dahilinde incelenmektedir. Bu kategorilerden arasında yüzde 22.13 ile "Bir Ressentiment (Hınç) Nesnesi Olarak Batı" kategorisi en büyük ağırlığı taşımaktadır. "Komplocu Bir Düşmanı Olarak Batı" kategorisine giren haberlerin oranı yüzde 20.01, "Taklit Edilmesi Gereken Bir Arzu Nesnesi Olarak Batı” kategorisininki ise yüzde 4.35 'tir.

TABLO 6: Ontolojik Karşıtlık Çerçevesi İçindeki Kategoriler

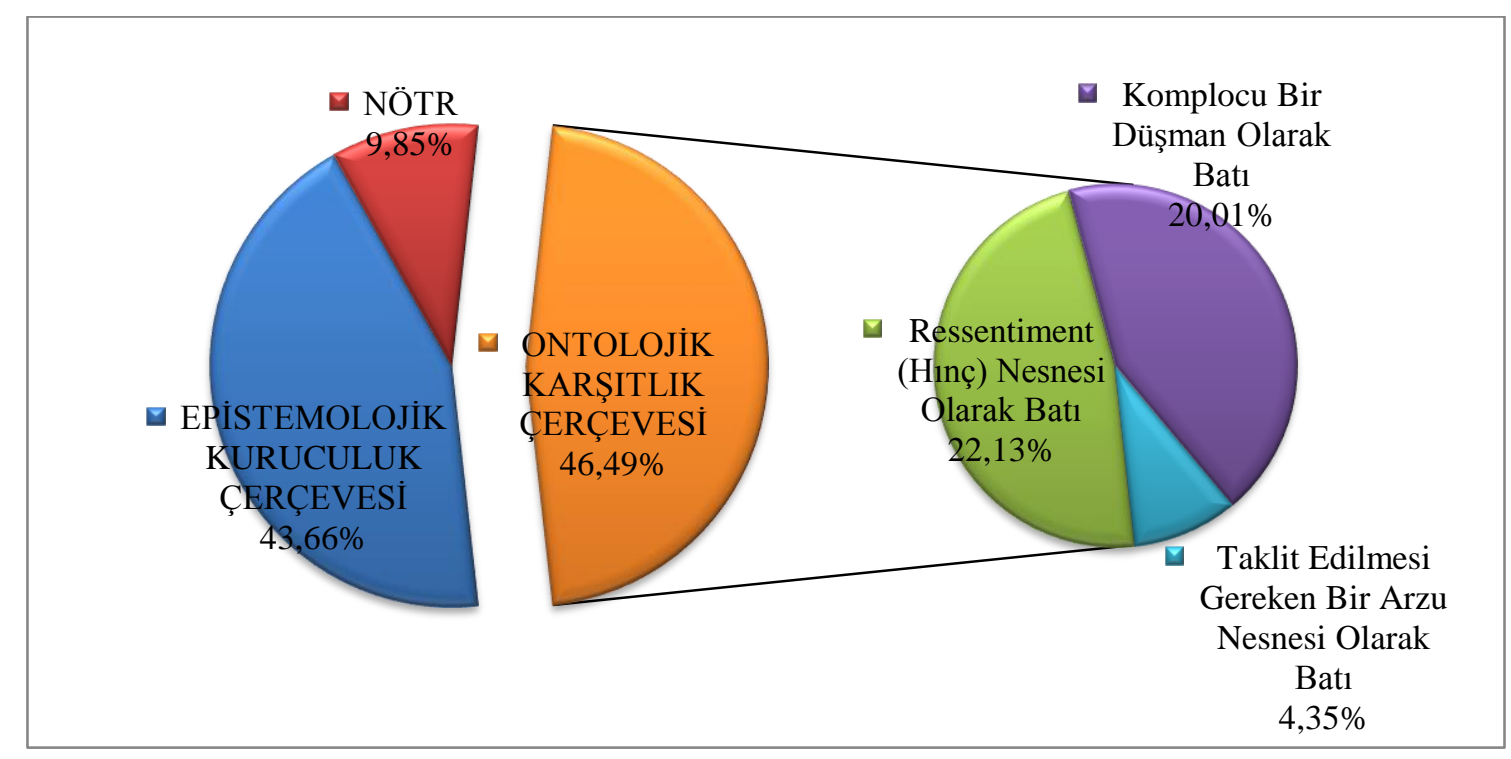

\section{Bir Ressentiment (Hınç) Nesnesi Olarak Batı}

Haberlerin yüzde 22.13'lük bir oranını oluşturan bu kategori, araştırmanın teorik çerçevesinde açıklanan Batı'ya ilişkin siyasal ve kültürel kavrayışın tarihi sürekliliğini göstermesi açısından önemli bulgular içermektedir. Bu kategorideki haber anlatısında, seçilmiş travmalar ve mağduriyetlerden faydalanılarak Batı fikrinin, insani nitelikler bağlamında sorgulanmakta olduğu; Batı'nın kurban isteyen bir nesne, Doğu'nun ise mağdur bir özne olarak temsil edildiğini söylemek mümkündür. Bu kategori dahilinde analiz edilen haberlerin yorumlanmasında, ilk olarak Nietzsche'nin “Ahlakın Soykütüğ̈̈” kitabında terimselleştirdiği “ressentiment” kavramı anahtar olacaktır. Ressentiment'ın kökeninde "bir acı çekenin” bir de "fail gereksinimi”"nin bulunduğundan söz eden Nietzsche, "Her acı çeken, içgüdüsel olarak acısına bir neden arar... (...)Hınç, intikam ve bunlara akraba şeylerin gerçek fizyolojik nedeni ancak burada bulunabilir kanımca, ıstırabı duygulanım yoluyla uyuşturma isteğinde yani..."der (2012, 132). Scheler'in zihnin kendini zehirlemesi olarak ifade ettiği ressentiment, hukuki eşitlik ile siyasi ve ekonomik eşitsizlikler arasındaki farkın ya da maddi zenginlik ile siyasi güçsüzlük arasındaki çelişkinin belirgin bir görünümüdür. Scheler, ressentiment'ın iki temel kökeni olduğunu belirtir: Bastırılmış intikam güdüsü ve haset $(2004,7)$.Ressentiment, ortaya çıkmak için bazı uyaranları sabırla bekler; yoksa da bulur.

Haberlerdeki Batı anlatısının Nietzsche ve Scheler'in kullandığı anlamda bir ressentiment'ın üretimine katkıda bulunup bulunmadığını tartışmadan önce, bu çalışmanın kuramsal çerçevesinde sözünü ettiğimiz Türk siyasi düşüncesindeki Garbiyatçı gramerin önde gelen kaynaklarından biri olan mağduriyet hissinin altını çizmek yerinde olacaktır. Soyut nitelikteki bu tespitlerin daha iyi anlaşlabilmesi için, TRT haberlerinde, gerek haber aktörü olarak çerçeve sponsoru konumunda bulunan grup ya da kişilerin; gerekse haber metninde yer alan ifadelerin genel niteliklerine bakmak gerekmektedir. Batı fikrinin, haberlerde “mă̆dur eden” olarak resmedildiği ifadelere şu örnekler verilebilir:

(ALT SES) “Özgür Suriye Ordusu Komutanı’na işkence yaptılar. ABD merkezli sosyal paylaşım sitesi, işkence görüntülerini yükleyenlerin kimliğini, emniyete (Türk Polisi Y.N.) vermedi. Polisin ısrarı üzerine verilen karşılık, daha da düşündürücü idi: Şirket yetkilileri görüntülerin Amerika'nın güvenliğini ilgilendiren bir tarafı olmadı̆̆ını bildirdi." (11 Nisan 2013 - TRT Haber ) 
(ALT SES) “Avrupa Kuzey Kutbu’na sıkışmış iki balinaya gösterdiği ilgi ve gayreti Suriye meselesinde göstermedi." (6 Haziran 2013 - TRT Haber)

(ALT SES) “Almanya müzakere başlığını Taksim'deki olaylar bahanesiyle engellemeye çallşsllyor." Haziran 2013 - TRT Haber)

(HABER AKTÖRÜ / TELEFONDA AÇIKLAMA) "Paris, Londra, Washington, Brüksel gerçek demokrasiyi İslam dünyasında istemiyor. Çünkü kendi çıkarlarını, İsrail'in çıkarlarını koruyamıyorlar. (...) Amerika başta olmak üzere Londra ve Brüksel'in olanlarda büyük bir sorumluluğu var." (27 Temmuz 2013 - TRT Haber / Canlı Yayın Konuğu Star Gazetesi Genel Yayın Yönetmeni Mustafa Karaalioğlu)

Araştırmanın nicel bulgularından ve yukarıdaki sınırlı sayıdaki alıntıdan yola çıkarak, hem kutsal hem de din dışı mağduriyet kavramlarının TRT haberlerindeki Batı fikrinin üretimine dikkate değer bir katkı koyduğunu söylemek mümkündür. Yukarıdaki, alıntılarda çerçevesi çizilen ilişkinin temel olarak gaddar ile gadre uğrayan diyalektiğini yansıttığı görülmektedir. Batı veya haber aktörlerinin nitelendirmesiyle "Paris, Londra, Washington ve Brüksel”, ya (Hristiyan) kendi için layık gördüğü demokrasiyi, biz (Müslümanlar) için gereksiz bulan homojen bir ressentiment nesnesine dönüştürülmekte, bu yolla kutsal bir mağduriyetin nedenini oluşturmaktadır; ya da diğer alıntılarda olduğu gibi "biz"e karşı çifte standartlı bir tutum içinde olan, kasıtlı olarak çıkarlarımızın aksi yönde davranan bir düşman halini almaktadır. Bu noktada, haber anlatısında resmedilen Batı'nın bir tür "seçilmiş travma" kaynağı olarak işlev gördüğünü iddia etmek olasıdır. Seçilmiş travma, bir grubun üyelerinde başka bir grubun üyeleri tarafindan aşağılanmışlık ve mağdur edilmişlik şeklinde yoğun duygular uyandıran bir olay anlamına gelmektedir (Volkan\&Itzkowitz 2002, 20). Mağduriyet, politik "biz" ve "öteki"nin oluşumunda kritik bir öneme sahiptir. Ancak, yaşanan mağduriyetin üstesinden gelebilmek için bireysel ve toplumsal anlamda, en ciddi olumsuz yansıma, insanlık dışına atma (de-humanisation) yönelimi olarak görülmektedir. Bu zihinsel mekanizma, sürece yayılan bir tür stereotipleştirmedir. Gruplararası ilişkilerde, ötekileştirmenin uç tarzlarından biri olarak kuramsallaştırılan $d e$ humanisation (insan-değil) kavramı, infra-humanisation (insanlıkta alçaltma) kavramı ile birlikte insanlık durumunda yarattığı hiyerarşik algı nedeniyle ayrımcılığın temelini oluşturur. İnsanlık dışına atma (de-humanisation) kavramı, iç gruba 'insani' özellikler atfedilirken, dış grubun bundan yoksun görülmesi/gösterilmesi olarak özetlenebilir (Volkan\&Itzkowitz 2002, 20). Çözümlemeye konu haberlerde Batı tasavvurunun, özellikle moral değerler açısından ciddi bir sorgulamaya tabi tutulduğu dikkat çekmektedir. Bu haberlerde insanlık dışına atma (de-humanisation) vurgusu sistematik bir anlatı olarak değil, söyleme sinmiş bir yönelim olarak dikkat çekmektedir. Çünkü Batı fikri, insanlığın gerektirdiği ulvi duyguların bir bölümünden yoksun; dolayısıyla "eksik insani”" nitelikler taşıyan yekpare bir bütüne atıfla üretilmektedir. Bu metinlerde, Batı'nın eksik insani niteliklerinin altı çizilmesine karşıı olarak gizli özne "biz", aklı ve vicdanı ile tam bir insandır:

(CAM SPIKER) 'Demokrasi vurgusu yapan AB, Rusya ve ABD'den hangi açıllamalar geldi ya da gelmedi. İzleyin siz karar verin..." (4 Temmuz 2013 - TRT Haber / Misır'da ordunun yaptı̆̆ 1 darbe sonrası değerlendirmeler)

(CAM SPIKER) "Misır'daki darbe dünya için samimiyet sinavina döndü. Demokratik değerleri ön plana çıkaran AB, sessiz kalırken Afrika Birliği Misır'ın üyeliğini askıya ald."” (5 Temmuz 2013 - TRT Haber / Mısır'daki darbe sonrası değerlendirmeler)

(ALT SES) "Demokrasinin beşiği olduğunu ilan edenler darbe diyemedi. Adeta darbeyi meşru gördü. Avrupa 'endişeyle izliyoruz. Askerin siyasete müdahalesinden yana değiliz' korusu ile aynı şeyi söyledi." (5 Temmuz 2013 - TRT Haber / Mısır'daki darbe sonrası değerlendirmeler)

(HABER AKTÖRÜ / GÖRÜNTÜLÜ AÇIKLAMA) "Demokrasi ve insan haklarl havariliği yapanların beyanlarının sadece lafta kaldığı ortaya çıktı.” (27 Temmuz 2013 - TRT Haber)

Yukarıdaki haber metinlerine bakarak, önerilen Batı fikri üzerine bir çıkarım yapmak mümkündür. Haberlerde yer alan ifadelerin Batı fikrini yekpare bir bütün olarak tarif etmeye yönelik olduğu söylenebilir. Söz konusu yekpare bütünlük, haber metinlerinde yer alan ifadelere göre, "Demokrasinin beşiği olduğunu iddia edenler", "Darbeye darbe diyemeyenler", "Demokrasi ve insan hakları havariliği yapanlar" ve "Sessiz kaldı̆̆ iç̧in utanması gerekenler"i de kapsamaktadır. Kullanılan bu metonimlerin ${ }^{2}$, Batı ülkeleri ve bunların yönlendirdiği öne sürülen uluslararası kuruluşlara karşıllık geldiği anlaşılmaktadır. İnsani niteliklerin bir bölümünden yoksun olarak resmedilen Bat1; iki yüzlülük, ahlaken noksanlık gibi olumsuz özelliklerle ilişkilendirilerek nesneleştirilmektedir. Bu nesneleştirmenin, barındırdığı duygusal ve ahlaki yargılamalar yoluyla stereotipleştirmeye ve ontolojik bir ayrım üretmeye yardımcı olduğu, Batı fikrini "insanlık olarak bütün olmayan bir varlık" şeklinde tanımlamaya yöneldiği iddia edilebilir. Bu söylemi Leen Boer'in yaptığı Garbiyatçılık tanımı ile ilişkilendirmek mümkündür. Boer, Garbiyatçılığı, “Batı, değerler

${ }^{2}$ Metafor, birbirinin yerine ikâme edilen terimler ilişkisini; metonim birbiriyle yan yana terimler ilişkisini ifade eder. Metafor benzerliğe dayanır ve dikey ilişkiye gönderme yapar; metonim ise yakınlığa dayanır ve yatay ilişkiye gönderme yapar (Bilgin 2003, 238). 
rasyonelitesi az, ancak araçsal akılcıllğı fazla olarak resmedilir. Batı zihni böylelikle yüksek düzeyde bir aptallı olarak görülür” ş̧eklinde tanımlamaktadır $(2004,152)$.

\section{Komplocu Bir Düşman Olarak Batı}

Çözümlemede elde edilen bulgular, örneklemi oluşturan haberlerin beşte birinde Batı fikrinin "Komplocu Bir Düşman" olarak üretildiğini göstermektedir. Tüm haberlerin yüzde 20.01'ine karşllık gelen bu kategorinin, Batı kavrayışının stratejik kullanımına radikal bir örnek oluşturduğu söylenebilir. $\mathrm{Bu}$ kategorideki araştırma bulgularının yorumlanmasında, Moscovici'nin önerdiği "temiz olan" ve "kirli olan" ayrımı, anahtar kavram olacaktır. Serge Moscovici'ye göre komplo teorileri; halkı, şeyleri ve eylemleri "temiz olan" ve "kirli olan" şeklinde ikiye ayırmaktadır: "Sosyal olmayan, ulusal olmayan her șeye karșlllk sosyal, ulusal olan her șey $(1996,48) . "$ TRT haberlerinde Batı kavrayışının, komplocu bir düşman olarak sunulmasına ilişkin ifadelere şu örnekler verilebilir:

SPIKER: "Uluslararası camiada bunu planlayanlartn hangi damarına baslldl. Ne istediler de Türkiye yapmadl?:HABER AKTÖRÜ / CANLI YAYIN KONUĞU: Bir senaryo var. Bir oynayanlar var. Küresel bir oyun oynandığı açık görülüyor. Arka kısımda ne olduğunu görmesi gerekiyor halkımızın. Mayıs ayında Türkiye'de ne var. Türkiye'de ne oldu." (14 Haziran 2013 - TRT Haber / Devlet Bakanı Fatma Şahin, Gezi Parkı olaylarını değerlendiriyor)

(HABER AKTÖRÜ / GÖRÜNTÜLÜ AÇIKLAMA) “Olayın dış bağlantılı olduğuna ilişkin elimizde somut deliller var. Sadece bir tek delil değil. Bir yargl sürecinde ve siyasi değerlendirme noktasındayız. Olayın iç ve dış boyutu üzerinde ciddiyetle duruyoruz. Bu olaylar adeta bir merkezden planlaniyor gibi olmuştur. Türkiye'de de muhtelif merkezlerin daha çok tahribat oluşturmasına ilişkin gayreti var." (10 Haziran 2013 TRT Haber / Hükümet Sözcüsü, Bakanlar Kurulu sonrası Gezi Parkı protestolarını değerlendiriyor)

(HABER AKTÖRÜ / GÖRÜNTÜLÜ AÇIKLAMA) “Uluslararası medya Türkiye'yle ilgili purlttll rüya görebilir mi? Bunların içerideki uzantıları Türkiye'yle ilgili hayırl rüya görebilir mi? Görsel medya ile yazılı medya ile iktidarımıza saldırıyorlar. Kimlerle birlikte bunlart yapıyorlar? Faiz lobisiyle birlikte yapiyorlar. Ulusal ve uluslararası faiz lobisi ile birlikte yapıyorlar. Borsa Lobisi enteresan, spekülatörler enteresan." (9 Haziran 2013 - TRT Haber / Başbakan, uluslararası medyanın Gezi Parkı olaylarıyla ilgili yayınlarını eleştiriyor)

$\mathrm{Bu}$ kategorideki haberlerin genel çerçevesi, öncelikle sınırları belirsiz bir "yabancı parmağı" söylemine dayanmaktadır. Bu yolla, "dost/bizden” olanların püritenliğini mütemadiyen bozan ve kirleten bir "düşman (öteki)" olduğundan bahsedilmektedir. Özellikle, haber aktörlerinin durum tanımları, Batı'nın son derece hegemonik ve başkalarının kaderi üzerinde de söz sahibi olmayı becerebilen oyun kurucu bir özne olduğu imgesini yaratmaktadır. Batı, yerine göre uluslararası toplum, yerine göre küresel medya ya da dünyanın tamamı olabilmektedir. Karl Popper, komplo teorilerini “(...) insanların genellikle hoşlanmadıkları savaş, işsizlik, yoksulluk, kıtlık dâhil- tüm toplumsal olayların bazı güçlü birey ya da gruplar tarafından planlandığı görüşü (...)"olarak tanımlamaktadır $(1990,142)$.

Çözümlenen haberlerdeki komplocu Batı imgesinin "temiz yerliler - kirli yabancılar" ikiliğinde algılanmasını mümkün kılan önemli bir veçhesini "iç mihrak" tanımı oluşturmaktadır. Yerlileri kovmak, ülkelerini elinden almak isteyen komplocu Batılılar'ın amaçlarına alet oldukları için "kirlenen" bu kesim, artık "büyük oyunun bir parçası" olmuştur. Tanıl Bora'nın deyimiyle, ideolojik olarak "zımmileştirilen" bu kesimlerin (1999, 33), yerliler nezdinde komplocu Batılllardan daha büyük bir öfkenin hedefi olduğunu söylemek mümkündür. TRT haberlerinde, özerk bireyler olarak değil komplocu Batı’nın bir uzantısı - ayrılmaz parçası, nesnesi - olarak temsil edilen bu kesimin dış güçlerin oyuncağı olduğuna, ya da safdillik yaptığına dair sistematik bir söylem oluşturulmuştur.

Haberlerde komplonun Batı imgesinin bir bileşeni gibi resmedilmesinin reel politik karşllıkları nedenleri olduğu gibi Türkiye'nin siyasal kültürü ile ilişkisi olduğu da söylenebilir. "Bizans oyunu" , "İngiliz tuzağı" vb. deyimlerle sözlüğe - ve kolektif belleğe - giren bu miras, on yıllara yayılan geniş bir bilinçaltının eseridir. Ancak, olumsuz olarak algılanan her gelişmede Yahudi parmağı, komünist tertip ya da siyonizm izi aramak Türkiye sağı için; Amerikan oyunu aramak Türkiye solu için yeni bir refleks değildir. Tanıl Bora, milli kimliğin inşa dönemindeki tekbenci (soliptist) bilinç hali ve devlet aygıtının aşırı hassas tehdit algısının da komplo zihniyeti için bereketli bir alan yarattığını vurgulamaktadir $(1996,45)$.

\section{Taklit Edilmesi Gereken Bir Arzu Nesnesi Olarak Batı}

Elde edilen bulgulara göre, TRT haberlerinde örneklemi oluşturan haberlerin yüzde 4.35'i Batı fikrinin "Taklit Edilmesi Gereken Bir Arzu Nesnesi” olarak üretildiğini göstermektedir. Batı kavrayışının bu kapsamda ele alındığına ilişkin haberlerde yer alan ifadelerden bazı örneklere aşağıda yer verilmiştir: 
(ALT SES) “Obama'dan Suriye’ye uyarı... Obama, Suriye’de kimyasal silah kullanıldiğı yönündeki iddiaları değerlendirdi. Obama "Bu oyunun kurallarını tamamen değiştirir." dedi. Şu anda elimizde deliller var diyen Obama, incelemenin en kisa sürede sonuçlandırllacağını söyledi. İnsanlar üzerinde kimyasal silah kullanılmasına izin vermeyeceklerini belirten Obama, sonuna kadar beklemeyeceklerini söyledi." (28 Nisan 2013 - TRT Haber)

(ALT SES) “ABD Başkanı Barrack Obama, Suriye’de kimyasal silah kullanıldı̆̆ına dair ellerinde kanıt bulunduğunu söyledi. Obama, silahları kimin nasıl kullandığını bilmediklerini söyledi. Suriye konusunda orduya "seçeneklere hazır olun" talimatını geçen yıl verdiğini belirten Obama, Suriye’ye gözdă̆ veren ifadeler kullandl." (30 Nisan 2013 - TRT Haber)

(HABER AKTÖRÜ / GÖRÜNTÜLÜ AÇIKLAMA) “Arzu ediyoruz ki Avrupa Birliği de vize politikasını biraz daha anlayışl hale getirir. Katı vize politikası doğrusu anlayamadı̆̆ımız bir husus.” (4 Mayıs 2013 - TRT Haber / Cumhurbaşkanı Abdullah Gül, Portekiz temaslarında AB'nin Türk vatandaşlarına vize uygulamalarını değerlendiriyor)

(HABER AKTÖRÜ / CANLI YAYIN KONUĞU) “Büyük devletleri gözardı ederek kritik sorunları çözmeniz mümkün değildir.” (15 Mayıs 2013 - TRT Haber / Başbakan’ın ABD ziyareti ile ilgili özel yayında Prof. Dr. Ramazan Gözen ABD’nin Suriye'deki çatışmalarla ilgili pozisyonunu değerlendiriyor)

Batı'nın "Taklit Edilmesi Gereken Bir Arzu Nesnesi” olarak kavranmasının temel unsurunu "güç" algısı oluşturmaktadır. Haber anlatısının tümünde, Batı'nın, erk sahibi bir aktör olduğu ve eylemlerini gerçekleştirme gücünü kendinde bulduğu görüşüne rastlanmaktadır. Batı, haberlerde geçen ifadelere göre, gerektiğinde karşıtına "gözdă̆ verebilen, kritik sorunları çözmek için gözardı edilmemesi gereken “büyük devletlerdir.” İlk alıntıdan anlaşıldığı üzere, büyük devlet demek, “oyunun kuralını koyan” ve bu kuralların bekçiliğini yapan anlamına gelmektedir. Ayrıca Batı, "biz”i de artık arasına alması beklenen, en azından vize politikası gibi meselelerde "anlayış” göstermesi istenen üstün bir kulüptür.

Türk siyasi düşüncesinde Batı'nın güç ve iktidar kavramlarıyla açıklanması, köklerini 300 yıllık tarihsel geri çekilme sürecinde bulur. Bu döneme kadar Dar'ül Harb ya da küfr diyarı olarak aşağılanan Batı medeniyeti, bitmek bilmeyen askeri yenilgilerin ardından üstünlük duygusunun yerle bir olması nedeniyle "sorunlu" denebilecek bir güç kavramıyla özdeşleştirilmiştir. Burada kastedilen sorun, Batı'nın bir yanı "Sosyal Darwinizm”e çalan bir tür “güç fetişizmi” ile beraber algılanmasıdır. Bu çalışmanın kuramsal çerçevesini çizerken de anlatıldığı gibi, Jön Türk düşüncesinde Batıcı eğilimlerin temel gereğinin aslında bir şekilde güce ulaşma arzusu olduğu göze çarpmaktadır. Bu eğilimin tarihi süreklilik taşıdığı da bir gerçektir. Kemalizm'in "Muasır Medeniyet" olarak yön tarifi yapmadan cisimleştirdiği şey, aslında o güne göre güçlü olan Batı medeniyetidir. Muasır medeniyet, II. Dünya Savaşı sonrası yeni güç dağılımına göre güncellenir ve bu kez “(...) dünyanın bugün her bakımdan en kuvvetli, en ileri ve en demokrat devleti olan Amerika ”ya da dönüşebilir (Bora, 2002, 152). Türkiye'de devleti yönetenlerden sokaktaki adama kadar, eksikliği hissedilen "güç" arzusuna, Batı'nın kuvveti vurgulanarak oluşturulan yanıt, Garbiyatçı fantazyanın önemli bir görünümünü oluşturmaktadır. Bu iktidar eksikliği ve buna bulunan Batı kaynaklı çare, türlü früstrasyonlar sonucu pekâlâ arzunun nefrete dönüşmesine de neden olabilir. Araştırmanın önceki bölümlerinde de vurgulandığ 1 üzere arzu nesnesi olarak yüceltilen şey, hınç nesnesine, komplocu bir düşmana evrilebilir. Lacan'ın "imkânsız arzu” kavramı ile ilişkilendirirsek (Bkz. Lacan, 2013), Batı'nın bu görünümünü, Türkiye'de iktidar iddia eden her birey ve kurumun söylemine sinen bir tür "fallus"* olarak değerlendirmek mümkündür. Batı, bu noktada bir türlü kapatılamayan güç eksikliğinin sembolüdür.

\section{Epistemolojik Kuruculuk Çerçevesi}

Çözümlenen haberlerde Batı fikrinin ontolojik ayrılık çerçevesi dışında, bir "biz” üretmeye ve pekiştirmeye katkı koyacak epistemolojisi dikkat çekmektedir. Bu çerçeve dâhiline giren haberlerin Batı kavramını betimlediği ölçüde, "biz" hakkında da fikir veren, referanslarda bulunan ve "biz"e kendimizi anlatan bir içeriğe sahip olduğu görülmektedir. Batı, bu noktada biz" üretmeye dönük bir performansın nesnesi olmuştur. Bulguların yüzde 43.65'ini oluşturan bu haberler, "Epistemolojik Kuruculuk Çerçevesi" içinde incelenecektir. Bu çerçevede oluşturulan üç alt kategori arasından örneklemde en geniş yer kaplayan yüzde 17.89'luk bir ağırlığa sahip olan "Bir Kimlik Kurucu Ayna Olarak Batı" kategorisi olmuştur. "Kıyas-Referans Noktası Olarak Batı” kategorisinin ağırlığı yüzde 17.02 olurken, "Popülizm Nesnesi Olarak Batı” kategorisinin oranı yüzde 8.74 olarak gerçekleşmiştir.

\footnotetext{
*Lacan, fallustan, annenin eksik, babanın ise sahip olduğu sanılan "şey” olarak; yani ötekinin (annenin) arzusunu arzulayan çocuğun ulaşmak istediği bir güç olarak bahseder. Bu arzu giderilemeyecektir, çünkü hayal edildiği gibi bir iktidar hiç olmamıştır, olmayacaktır. (Bkz. Lacan, 2013).
} 
TABLO 7: Epistemolojik Kuruculuk Çerçevesi İçindeki Kategoriler

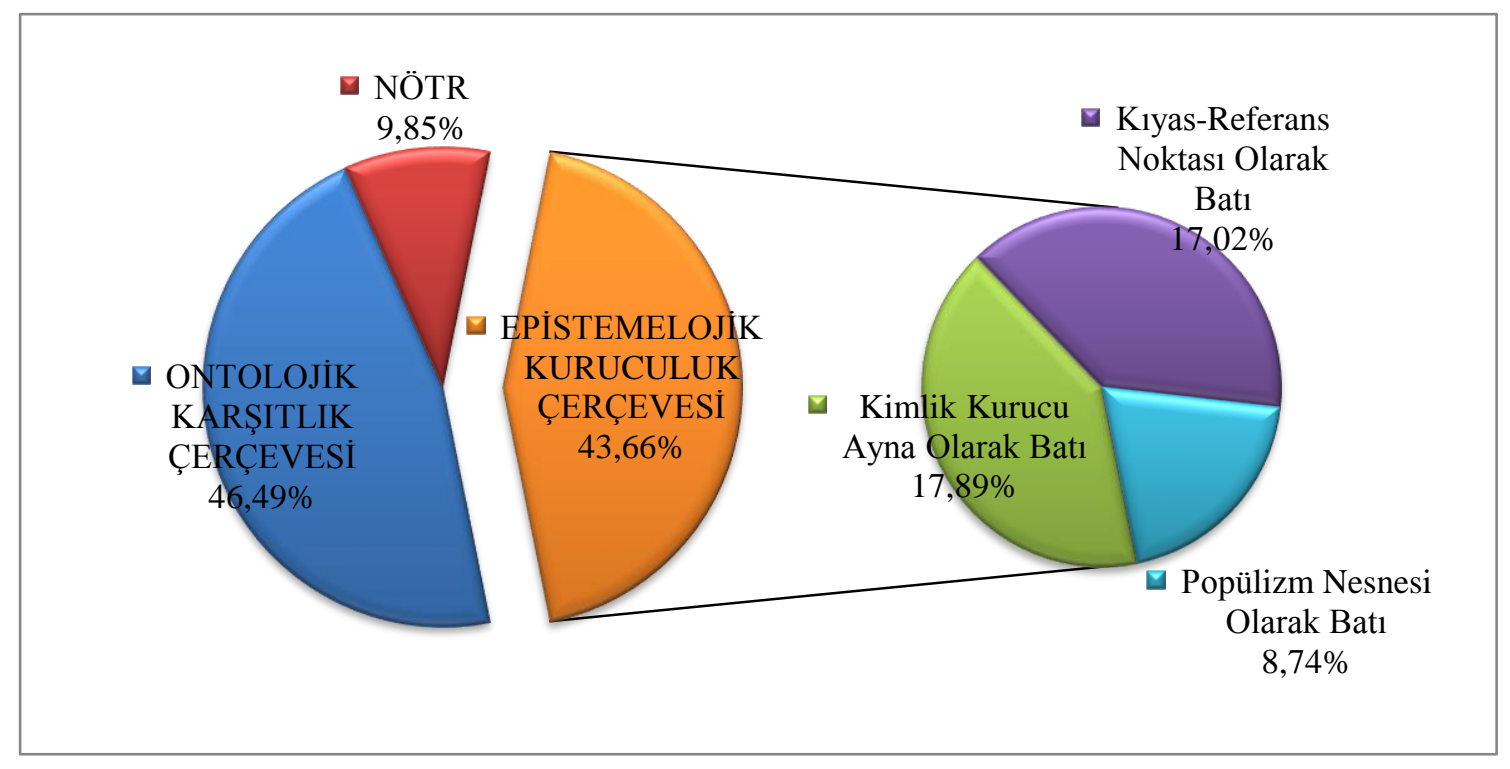

Kimlik Kurucu Ayna Olarak Batı

Çözümlenen haberlerin yüzde 17.89’luk bölümü bu kategoriye girmektedir. Bu haberlerin genel vurgusu, Batılı öznenin nesneleştirilmesiyle - çoğu zaman onun adına konuşma hakkının da ele geçirilmesiyle - "biz"e ait niteliklerin ve konumun onaylanmasına yöneliktir. Bu kategoriye giren haberlerden bazıları, aşağıdaki alıntılarında yer almaktadır :

(ALT SES) “Başbakan'ın ABD ziyaretinde bir ilk yaşanacak. Erdoğan devlet başkanlarına uygulanan A Protokolü ile ağırlanacak. Blair House'da kalacak." (22 Nisan 2013 - TRT Haber / Başbakan'ın ABD ziyareti öncesi hazırlığı anlatan haber)

(MUHABİR ANONS) “Washington Başbakan'ı bekliyor... Başbakan, ABD ziyareti sırasında üst düzey protokolle ağırlanacak. ABD Erdoğan'ın ziyareti için günler öncesinden hazırlanmaya başlandı. Başbakan için iki ayrı tören düzenlenecek. Beyaz Saray'da ve Obama görüşmesi öncesi. Gösterilen önemin en belirgin taraflarından biri Başbakan'ın Blair House'da ağırlanacak olması. Burası sadece seçkin misafirler için ă̆ırlanıyor." (14 Mayıs 2013 - TRT Haber / Başbakan'ın ABD ziyareti öncesi son gelişmeler anlatılıyor)

(ALT SES) “Başbakan Erdoğan Washington'da üst düzey törenle karşılandl. Tören öncekilerden farklıydı. Sadece devlet başkanları için uygulanan protokol uygulandı. (MUHABIR ANONSU) Aslında burası trafiğe açık bir alan. Ancak özel bir ziyaretçi olduğunda Blair House açıllyor ve bu cadde trafiğe kapatılıyor. Blair House'da sadece özel misafirler ağırlanıyor." (15 Mayıs 2013 - TRT Haber / Başbakan'1n ABD ziyareti öncesi son gelişmeler anlatıliyor)

(HABER AKTÖRÜ / GÖRÜNTÜLÜ AÇIKLAMA) “Hepimizin didinerek oluşturduğu bir Türkiye imajı var. Türkiye 'nin imajını korumalıyız.” (18 Haziran 2013 - TRT Haber / Cumhurbaşkanı, Gezi Parkı protestolarını ve polisin tutumunu değerlendiriyor)

Örneklerde yer alan ifadelerin tümünün, "biz"in üzerindeki hayali bir "Batılı bakışı”nı (Western gaze) anlatmakta olduğu söylenebilir. Ahıska’ya göre, Batılı bakışı, batı temsili ya da batı-dışının ikircikli kimliği gibi Garbiyatçılığın ele almak durumunda olduğu, çünkü hem Batı temsilini hem batı-dışının kararsız ve karmaşık kimliğini etkileyen bir niteliğe sahiptir (Ahıska, 2003, 365). Batılı bakışı'nın TRT haberlerindeki işlevini en kaba haliyle "Batı'nın 'biz'e nasıl baktığını anlatmak" olarak tanımlamak mümkündür. Bu bakışın öznesi Batı, nesnesi "biz” iken; haberler dolayımı ile ikincil bir tanımlama yapılarak, bakışın kendisi nesneye dönüştürülmüştür. Artık, o bakışın ne olduğu ya da olmadığ1, nasıl anlaşılması gerektiği yeniden tanımlanmakta ve yeni bir anlatı yaratılmaktadır. Anonim bir Batılı gözün gördükleri, "biz” kimliğinin tanımlanması için anahtar rol oynamaktadır.

Kadığlu'na göre,düşünceden çok simgelere itibar eden(1999, 29),Türk modernleşmesi için, dış gözlemcinin varlığı bir hayatiyet sahasıdır.Bir başka deyişle, geç modernleşmenin yarattığı güvensiz ve ikircikli ruh hali için özne 
olmanın yolu, bir başkasının aynasından yansıyan görüntülerden geçer. Aynanın bu konuda "yaralanmış bilinçler" için nasıl bir fonksiyona sahip olduğunu açıklama adına Lacan'ın "ayna evresi” kavramı, zihin açıcı bir perspektif sunmaktadır. Gelişim psikolojisine göre, birey doğuştan benlik sahibi değildir. Lacan, özne olmanın; başkalarının dolayımı ile fark edildikten sonra benliğin gerçekleşebileceğinden söz eder. Lacan'a göre bebek, anneye bakınca, aslında sembolik olarak bir aynayla karşılaşır. Şayet erkek ise anneden farklı olduğunu, kız ise anneye benzer olduğunu keşfeder. Dolayısıyla insan, bir başkası aracılığı ile benliğini fark eder ve inşa eder (Lacan, 1949). Ayna evresi, bireyin tarihinde gelip geçen bir evre olmaktan çok, öznenin kesintisiz olarak kavgasını verdiği bir mücadelenin, kendini inşa etme çabasının bir alanıdır.

Çözümlenen haberlerde Batı'nın bir tür ayna olarak resmedilmesi dikkat çeken önemli bir noktayı oluşturmaktadır. Batılı aynadan yansıyan simgelerin, imajların sosyal itibar (social-esteem) adına sistematik olarak maniple edildiğini söylemek de mümkündür. Aynanın varlığı, ondan yansıyanlar; öznenin varlık-yokluğu için nasıl hayati bir mesele ise Türk düşünce hayatında dış bakış, özellikle Batı'dan yansıyan bakış o ölçüde önem arzetmektedir. Ziya Gökalp'in "Garp medeniyet dairesinin içinde" diye tanımladığı Türkiye için iktidarların meşruiyet skalası, sadece yurttaşların onayı ile tamamlanmamaktadır. Aynı zamanda müttefiklerin, uluslararası kuruluşların, hatta rakiplerin ve düşmanların bakışı da meşruiyetin tamlığı için birer parametredir.Daha yakın bir tarihte, 1996 yılında yapılan Habitat toplantısı öncesi yabancı konuklar görmesin diyerek sokak çocuklarının İstiklal Caddesi'nden toplanması, eylem yapan memurların "Ülke imajina menfi etki istihbaratı(Talu1996)" nedeniyle coplanması gibi ilginç tepkilere de neden olabilen bir bakıştır bu.

Son tahlilde, bu araştırmada erişilen bulgulara göre "Bir Ayna Olarak Batı Bakışı"nın Garbiyatçllık bağlamında çift yönlü işlevi bulunduğu düşünülmektedir. Bunlardan ilki, hayali bir Batılı bakışı aracıllğıyla Batı dışında Batı temsillerinden birinin oluşturulmasıdır. İkinci olarak ise ayna metaforu ile simgeleșen söylemin, yani Batı'nın nasıl baktığının Batı dışına anlatımının, hem bir "biz" yaratmaya, hem de yine "biz" için "dışsal meşruiyet" kaynağı olmaya hizmet etmesidir. Çünkü, Batılı bakışı kadar, onun ne olduğunu tarif etmek ve yönlendirmek de bir iktidar alanı açmaktadır.

\section{Kiyas-Referans Noktası Olarak Batı}

Türkiye'de Batı fikrinin tarihsel olarak inşasına bakıldığı zaman, etik ve politik bir referans noktası olması durumu da olağan görünmektedir. Bu çalışmada yapılan haber çözümlemesinde, "Kıyas-Referans Noktası Olarak Batı" kategorisine giren haberlerin oranı yüzde 17.02 olmuştur. Bu kategoriye alınan haberlerin temel olarak Batı fikrini, hem meşru bir referans noktası, hem de "biz"le benzeşen, öyle olması istenen, bir doğrulama skalası olarak ürettiği söylenebilir. Aşağıda yer alan haberlerdeki ifadeler, bu kategoriye örnek olarak gösterilebilir:

(HABER AKTÖRÜ / YAZILI AÇIKLAMA) “Cumhurbaşkanı Gül, Türkiye'de yaşanan son olayların Ortadoğu ülkelerindeki olaylara benzemediğinin altını çizerek, 'Bunlar aslında demokratik ülkelerdeki meselelere benziyor. İspanya İngiltere ve Amerika'daki olaylara benziyor. Türkiye'deki olaylar faili meçhuller kalksin diye yapılmıyor.' dedi. Gül, 'Türkiye'nin imajinı bozmaya kimsenin hakk yok' dedi." (6 Haziran 2013 - TRT Haber / Cumhurbaşkanı Gezi Parkı protestolarını değerlendiriyor)

(HABER METNI/ALT SES) "Büyük tartışmaya neden olan eylemler bu görüntülerle tarihe geçmişti. Yönetimin uygulamasına yönelik tepkiler Avrupa'da da yaşandı. Fransa'da göçmen olayları oldu. Bu görüntüler de İngiltere'den. Ekonomik kriz nedeniyle sık sık sokaklara dökülen Yunanlılar da aynı manzarayla karşı karşıya kalyyor." (8 Haziran 2013 - TRT Haber)

(SPIKER ANONS): "İstediğim kadar, istediğim yerde, istediğim zaman eylem yapartm gibi bir hak yok. İste uzman görüşü ile eylemlere polisin müdahale sinirlart:(HABER AKTÖRÜ / UZMAN GÖRÜŞÜ) Kalabalıklara dağllması gerektiği söylendikten sonra dağllmıyorsa orantısı güç ihtimali ortaya çıkar. Ben istediğim zaman istediğim yerde istediğim kadar dururum anlayıı̧ına karşı tutum, Ingiltere'de de böyledir; dünyada da böyledir. Mesela, Ingiltere'de Buckingham Sarayl önünde eylem yapamazsinız. Dünyanın her tarafinda bu böyledir" ( 1 Temmuz 2013 - TRT Haber / Gezi Parkı protestolarında polisin orantısız güç kullandığı iddialarını Prof. Dr. Mesut Eryılmaz değerlendiriyor)

Bu kategoride incelenen haberlerin, Garbiyatçı anlatı ile öncelikli ilişkisi, Batı'nın Batı dışındaki görünümlerinin oluşmasında temel etmenlerin büyük ölçüde kıyas ve referansa dayanması dolayısıyladır. Kıyas ve referansa dayalı çıkarımlar, bilişsel bir süreç olan sosyal kategorizasyon sonucunda üretilmektedir. $\mathrm{Bu}$ çalışmada, sosyal kategorizasyonun Batı'yı inşa etme biçimlerine katkısı, dış grup oluşturma bağlamında ve çeşitli temalar altında incelenmiştir. Çözümlenen haberlerin, Batı bilgisini bir kıyas ve referans noktası olarak üretmesinin, ontolojik ayrımın tersine bir motivasyonla olduğunu söylemek mümkündür. Batı, bu kategori dâhilinde incelenen haberlerde bir dış grup olarak görülmekten çok, iç grup olması istenendir. Capozzo ve Nanni'nin vurguladığı gibi, insan, kategoriler-arası farklılıkları abartmaya ve kategori-içi farklılıkları küçümsemeye eğilimlidir (1986). "Bu sayede iç-grup kendi içinde, dış-grup da kendi içinde tektipleştirilir (homojenizasyon) ve iç ve dış gruplar arasındaki farklar büyütülerek, iki grup arasındaki mesafe açılır (Paker 2012, 47)." Batı'nın bir kıyas ve referans noktası olarak üretildiği haberlerde, Türkiye 
ile Batı arasındaki bireysel özgürlükler vb. konulardaki farklar önemsiz addedilirken, güvenlik politikaları, çevre gibi toplumsal sorunlardaki benzerlikler ise ön plana çıkarılmaktadır.

\section{Popülizm Nesnesi Olarak Batı}

Bu kategoride yer alan haber metinlerinin genel karakteristiği Batı fikrinin "biz" oluşturmak ve meşruiyet kurmak için araçsallaştırılmasıdır. İncelenen örneklemin yüzde 8.74'ü bu kategoride yer almaktadır. Bu kategoriye giren haberlerde yer alan ifadelere örnek olarak aşağıda yer alan bazı alıntıları verebiliriz:

(HABER AKTÖRÜ / GÖRÜNTÜLÜ AÇIKLAMA) “Dünyada bir olay olmasın ki Türkiye onunla ilgili olmasın. Somali'yi konuşanlar Afrika'yı konuşanlar Türkiye'den bahsedecek. Artık ne söylenirse kafasını sallayan bir Türkiye yok. Dış dünyayla temasını kesmiş, sıkıştığı zaman Avrupa'dan para isteyen bir Türkiye yok” (14 Nisan 2013 - TRT Haber / Başbakan Yardımcısı Bülent Arınç, Fransa'da basın toplantısı yapıyor)

(HABER AKTÖRÜ / GÖRÜNTÜLÜ AÇIKLAMA) “Sayın Kerry (ABD Dışişleri Bakanı Y.N.), Türkiye’ye üçüncü mü, dördüncü mü defadır geliyor. Ancak doğrudan 'Sayın Başbakan'ın Mayıs ayı içinde Gazze'ye gitmesini arzu etmiyoruz' şeklindeki açıklaması diplomatik açıdan mahzurludur. Çünkü, ne zaman bir Türk yetkilinin nereye gideceğine hükümetimiz karar verir. Bunu Sayın Kerry de bilir ki Türkiye ne zaman ne arzu ediyorsa bunu gerçekleştirebilecek bir güçtedir." (22 Nisan 2013 - TRT Haber / Başbakan Yardımcısı Bülent Arınç, Bakanlar Kurulu sonrası basın toplantısı yapıyor)

(ALT SES) “Dışişleri Bakanı Ahmet Davutoğlu Gezi Parkı olayları ile ilgili ABD’den gelen üst üste açıkmalamalar karşısında John Kerry'yi aradl ve tepkisini dile getirdi. Davutoğlu, 'Türkiye ikinci sınıf bir demokrasi değildir' dedi." (5 Haziran 2013 - TRT Haber / Dişişleri Bakanı Ahmet Davutoğlu'nun ABD Dışişleri Bakanı John Kerry ile telefon görüşmesi)

(SPİKER) “Avrupa Parlamentosu'nun hükümeti eleştiren kararı, Ankara’dan çok sert tepki gördü. Dışişleri 'Türkiye muz cumhuriyeti değil' yanıtını verdi. (HABER AKTÖRÜ / GÖRÜNTÜLÜ AÇIKLAMA) Türkiye kimseden ültimatom alacak bir ülke değildir. Ben bunların, kendi saçmalama özgürlükleri çerçevesinde değerlendirilmesi gerektiğini düşünüyorum.” (13 Haziran 2013 - TRT Haber / AP Parlamentosu'nun Türkiye'yi polisin orantısız güç kullanması konusunda eleştiren kararını AB'den Sorumlu Devlet Bakanı Egemen Bağış yorumluyor.)

Dış politikada radikal değişiklikler yapmadan, Batı'ya karşı bu türden sözel meydan okumaların, iktidarlar için iç siyasette geniş bir manevra alanı yarattığını söylemek mümkündür. Kemalist Batıcılığı - çok önemli farklılıklar içerse de - Tanzimat Batıcılığı'nın bir devamı gibi görmeye eğilimli olan; Lozan'dan bu yana devlet eliti ile Batı arasında bir dizi gizli uzlaşı olduğu kuşkusunu taşıyan milliyetçi-muhafazakâr düşünce dünyasında (Bora 2008, 260); Batı'ya karşı kullanılan dilin, eylem kadar, hatta çoğu kez eylemden daha önemli bir rolü bulunmaktadır. Bu tarz bir meydan okuma dilinin, "şahsiyetli dış politika” benzeri taleplerle 2000'li yıllara kadar muhafazakâr sağ siyaseti sıkıştırdı̆̆g; ancak daha sonra kendi mecrasını bularak özerk bir söyleme dönüştüğü görülmektedir. Nitekim haber aktörlerinin ifadelerinde “Artık ne söylenirse kafasını sallayan bir Türkiye yok” denilerek dış politikada da bir "sıfır noktası” yaşandığının altı çizilmektedir. Bu kategoride çözümlenen haberlerde, Batı fikrinin "biz”in üretimine katkı koymanın yanında, geçmişle bugün ve gelecek arasındaki farkı vurgulamaya yönelik olarak inşa edildiğini söylemek de mümkündür.

\section{SONUÇ}

Bu çalışmada, “TRT haberlerinde 'Batı' fikri nasıl inşa edilmektedir?” sorusuna yanıt aranmıştır. Çalışmada, TRT haberlerinde Batı fikrinin hangi temel kategoriler çerçevesinde üretildiğini anlamak; haberleri, kaynaklar ve haber aktörleri bağlamında incelemek; haber metninin içeriğindeki süreksiz(episodik)-tematik, ahlaki-teknik çerçeveler aracılığıyla Batı anlatısına yüklenen moral değerleri, iktidar ilişkisi bağlamında sorgulamak ve haberlerdeki Garbiyatçı öğelerin, düşünce ve siyaset alanında geçmişten bugüne oluşmuş Batı imgesi ile etkileşimini vurgulamak amaçlanmıştır.Elde edilen bulgular ışığında, TRT haberlerinde Batı kavrayışına ilişkin şu değerlendirmeleri yapmak mümkündür:

> Araştırmaya konu edilen 4 ay boyuncatoplamhaber süresinin yüzde 10.92'si Batı kavramı ile ilişkilidir. Dış haberler arasında Batı kavramıyla ilgili olanların oranı yüzde 59.94 oranındadır. Bulgu, Türkiye için Batı'nın, halâ, önemli bir referans noktası olduğunu göstermektedir.

> Haberlerde, Batı fikrinin üretimi, büyük oranda haber aktörlerinin yaptıkları durum tanımlarına bağımlıdır. Batı kavrayışının en önemli üreticisi, haberlerin yüzde 39.84'ünde haber aktörü olarak görülen Başbakan olmuştur. Hükümet üyelerinin oranı ise yüzde 14.5'tir. Bu bağlamda, tüm örneklemin yüzde 54.34'ünde 
çerçeve sponsoru olan siyasi iktidarın Batı kavramının inşasında en önemli hegemonik aktör olduğu söylenebilir.

Batı kavrayışının moral değerlerle ilişkilendirildiği görülmektedir. Haberlerin yüzde 32.58'inde Batı, ahlâki olarak sorgulanmaktadır.

$>$ Yapılan konu odaklı çerçeveleme analizi sonucunda, haber anlatısının Batı fikrine ilişkin barındırdığı iki temel çerçevenin "yerlilik” ve "yabancılık” tanımı yapmaya yönelik olduğu gözlenmiştir. Buna gore, TRT haberlerinde Batı fikrinin Ontolojik Karşıtlık ve Epistemolojik Kuruculuk olarak çerçevelenmesinin oldukça yakın değerlerde olduğu görülmektedir. Haberlerin yüzde 46.49’u Ontolojik Karşıtlık Çerçevesi içinde yer alırken, yüzde 43.66'sı Epistemolojik Kuruculuk Çerçevesi'ne yönelik görünmektedir. Bulguların yüzde 9.85'i ise araştırma amaçlarına göre anlamlı bir sonuç içermediğinden kodlanamamıştır. Her iki çerçeveye ilişkin bulguların nicelik olarak birbirine yakın rakamlara karşılık gelmesi, haberlerdeki Batı anlatısının hem sınıflayıcı ve kategorize edici, hem de "biz" tanımı oluşturmaya yardım eden çifte fonksiyona sahip olduğunu göstermektedir.

> Haberlerde üretilen Batı kavrayışı, bu araştırmanın kavramsal çerçevesini oluşturan Garbiyatçılık kavramı için önerilen tanıma uygundur. Haberlerde Batı fikri, güncel pragmatik çıkarlara uygun olarak üretilmekte ve tüketilmektedir. Batı ile kurulan ilişkinin niteliğine göre çeşitli Batı görünümleri söz konusudur.

Batı fikrinin inşasında Osmanlı/Türk siyasi düşüncesi ve popüler kültürü içinde şekillenen bir repertuvardan faydalanılmaktadır. TRT haberlerindeki Batı görünümlerini, daha önce deneyimlenmiş bilgi stoklarından ödünç alınmış söylemler olarak görebiliriz. Araştırma sonuçları, Batı fikrinin bu bilgi stoğuna uygun olarak çerçevelendiğini ve kategorize edildiğini göstermiştir.

> Batı ile tarihsel olarak kurulan eşitsiz ilişki pratiğinin Türk siyasi düşüncesi üzerinde oluşturduğu izler haber anlatısında belirgindir. Batı, Türkiye'ye yakıştırılan - ya da Türkiye'nin kendine yakıştırdığı köprü olma metaforuna yaraşır biçimde, arzu nesnesi olmakla ressentiment (hınç) nesnesi olmak arasında salınmaktadır. Haberlerde, Batı fikrinin, araçsal akılla özdeş, vicdani noksanlıkla malûl, yozlaşmış bir insani eksiklik olarak üretilmesinde çalışmanın tarihsel arkaplanında sözü edilen milliyetçi - muhafazakâr düşünce dünyasındaki negatif Batı imgesinden izler görülmektedir. Batı'nın taklit edilmesi gereken bir arzu nesnesi olarak görünümü ise, temelde güçlü olmak, iktidara sahip bulanmakla ilişkilendirilmektedir. Garbiyatçı gramer, Batı fikrinin konjontürel olarak üretilmesine olanak tanıdığı oranda bir iktidar alanı oluşturulmasını da sağlamaktadır. Arzu, nefret ilişkisinin imkân verdiği geniş bir manevra sahası vardır. Bu imkân, iktidar üreten bir kaynak olarak kullanılmaktadır.

> Türkiye'ye karşı komplo kuran yekpare bir parça olarak Batı'nın varlı̆̆ı, uluslararası medya gibi Batılı kurumların da bu bütün içinde homojenize edilişi; Garbiyatçı söylemin yerel iktidarı konsolide etmek için seferber edilmesine tipik bir örnektir. Bu durum, Türk siyasi kültüründe komplo söylemine tanınan kredinin büyüklüğü dikkate alındığında, “öteki”nin özcü tanımlamalar ile sabitlendiği anlamına gelmektedir.

\section{KAYNAKÇA}

Ahıska, Meltem. 2003. "Occidentalism: The Historical Fantasy of The Modern”,The South Atlantic Quarterlyİçinde, 102(2/3), Spring-Summer, 351-79.

Ahıska, Meltem. 2009. “Garbiyatçılık: Türkiye'de Modernliğin Grameri”, Modern Türkiye’de Siyasi Düşünceİçinde. Cilt 9, 1039-66. İstanbul: İletişim Yayınları.

Atabek, Ümit. 2007. “İçerik Çözümlemesi: İletişim Çalışmalarının Olağan Yöntemi”, Medya Metinlerini Çözümlemek, Içerik, Göstergebilim ve Söylem Çözümleme Yöntemleri İçinde.1-18, Derleyen: Gülseren Şendur Atabek-Ümit Atabek, Ankara: Siyasal Kitabevi.

Bayar, Celal. 1999.Celal Bayar'ın Söylev ve Demeçleri (1933-1955). İstanbul: Türkiye İş Bankası Yayınları.

Belge, Murat. 2002. "Batılılaşma: Türkiye ve Rusya”. Modern Türkiye’de Siyasi Düşünceİçinde.Editör: Uygur Kocabaşoğlu. Cilt 3, 43-68, İstanbul: İletişim Yayınları. 
Berkes, Niyazi. 2002. Batıcılık, Ulusçuluk ve Toplumsal Devrimler. İstanbul: Kaynak Yayınları.

Berelson, Bernard. 1952. Content Analysis in Communication Research. New York: Free Press.

Bilgin, Nuri. 2003. Sosyal Psikoloji Sözlüğ̈̈: Kavramlar, Yaklaşımlar. İstanbul: Bağlam Yayıncılı.

Bilgin, Nuri. 2006. Sosyal Bilimlerde İçerik Analizi. Ankara: Siyasal Kitabevi.

Boer, Leen. 2004. "Struggling With-Isms: Occidentalism, Liberalism, Eurocentrism, Islamism". Third World Quarterly. 25(8). 1541-48.

Bora, Tanıl. 1996. “Komplo Zihniyetinin Örnek Ülkesi Türkiye”. Birikim. İstanbul: Birikim Yayınları.(90), $42-44$.

Bora, Tanıl. 1999.Türk Să̆ının Üç Hali.İstanbul: Birikim Yayınları.

Bora, Tanıl. 2008.“Milliyetçi Muhafazakâr ve İslâmi Düşünüşte Negatif Batı İmgesi”, Modern Türkiye'de Siyasi Düşünceİçinde.Editör: Uygur Kocabaşoğlu. Cilt 3, 251-69. İstanbul: İletişim Yayınları.

Boroujerdi, Mehrzad. 2001. Iran Entelektüelleri ve Batı. İstanbul: Yöneliş Yayınları.

Buruma, Ian \& Margalit, Avishahi. 2009.Garbiyatçılık: Düşmanlarının Gözünden Batı. Çeviren: Güven Turan.İstanbul: Yapı Kredi Yayınları.

Chatterjee, Partha. 1996. Milliyetçi Düşünce ve Sömürge Dünyası.Çeviren: Sami Oğuz. İstanbul: İletişim Yayınları.

Chen,Xiomei. 1995. Occidentalism: A Theory of Counter Discourse in Post Mao China. New York: Oxford University Press.

De Vreese, Claes \& Jochen Peter \& Holli A. Semetko. 2001. "Framing Politics at the Launch of the Euro:A CrossNational Comparative Study of Frames in the News".Political Communication. 18. 107-22.

De Vreese, Claes. 2004. "The Effects of Frames in Political Television News on Issue Interpretation and Frame Salience". Journalism and Mass Communication Quarterly. 81(1). 36-52.

De Vreese, Claes H. 2005. "News Framing: Theory and Typology”.Information Design Journal+Document Design. 13(1). 51-62.

Dora Capozza \& Renato Nanni. 1986. "Diffrentiation Processes for Social Stimuli With Different Degrees of Category Representativeness”. European Journal of Social Psychology.16. 399-412.

Entmann, Robert. 1993."Framing: Toward Clarification Of AFractured Paradigm”. Journal of Communication, 43(4). 51-58.

Gitlin, Todd. 1980.The Whole World is Watching. Berkeley: University of California Press.

Goffman, Erving. 1986. Frame Analysis.Boston: Northeastern University Press.

Göle, Nilüfer. 2004. “Bat1-Dışı Modernlik Üzerine Bir İlk Desen”, Doğu Batı, 1(2). 65-75.

Hanefi, Hasan. 2007. "Oryantalizmden Oksidentalizme”. Uluslararası Oryantalizm Sempozyumu: 9-10 Aralık 2006. Çeviren: Hakan Çopur. Editör: Lütfi Sunar.79-91.İstanbul: Büyükşehir Belediyesi Kültür Müdürlüğü Yayınları.

Holsti, Ole Rudolf. 1969. “Content Analysis”. The Handbook of Social Psychology, Second Edition, Vol:2 içinde, (Ed.) Gardner Lindzey \& Elliot Aranson, Addison-Wesley Publishing Company. 596-692.

Iyengar, Shanto. 1991. Is Anyone Responsible?. University of Chicago Press.

Iyengar, Shanto. 1997. “Siyasette Erişim Yanlılı̆̆ı: Televizyon Haberleri ve Kamuoyu”. Medya Kültür Siyaseṫ̇çinde. Derleyen: Süleyman İrvan.233- 53. Ankara: Ark Yayınevi. 
Kadığlu, Ayşe. 1999. Cumhuriyet İradesi Demokrasi Muhakemesi.İstanbul: Metis Yayınları.

Koçak, Cemil. 2006. Belgelerle İktidar ve Serbest Cumhuriyet Fırkası. İstanbul: İletişim Yayınları.

Lacan,Jacques. 2013. Fallus'un Anlamı. İstanbul: Altıkırkbeş Yayınları.

Lacan, Jacques. Tarihsiz. "Psikanaliz Deneyiminin Ortaya Koyduğu Biçimiyle"Özne-Ben"in İşlevinin Oluşturucusu Olarak Ayna Evresi”. 17 Temmuz 1949 Zurih Uluslararası 16. Psikanaliz Kongresi'ne Sunulan Bildiri. (Çev.) Nilüfer Kuyaş. Felsefe Yazılarl-1, Yazko Yayınları.http://www.elestirelpsikoloji.org/eleps/eleps/lacan.html Erişim Tarihi: 14 Ocak 2014.

Lewis, Bernard. 1984. Modern Türkiye’nin Doğuşu. Çev: Metin Kıratlı. Ankara: Türk Tarih Kurumu Basımevi.

Mardin, Şerif. (1996).Yeni Osmanlı Düşüncesinin Doğuşu, Çev: Mümtaz’er Türköne-Fahri Unan-İrfan Erdoğan, İstanbul: İletişim Yayınları.

Meşe, Gülgün. 1999. Sosyal Kimlik ve Yaşam Stilleri. İzmir: Ege Üniversitesi Sosyal Bilimler Enstitüsü Psikoloji Anabilim Dalı Yayınlanmamış Doktora Tezi.

Moskovici, Serge. 1996. "Yabancı Parmağı: Komplo Zihniyeti”. (Çev.) Hacer Harlak. Birikim. 90. 45-59.

Negrine, Ralph \& Newbold, Chris \& Hansen, Anders. 1998. Mass Communication Research Methods. London: MacMillan.

Nietzsche, Friedrich. 2012. Ahlakın Soykütüğü - Bir Polemik. (Çev.) Zeynep Alangoya. İstanbul: Kabalcı Yayınları.

Oran, Baskın. 1999.Atatürk Milliyetçiliği.Ankara: Bilgi Yayınevi.

Özlem, Doğan. 2002. “Türkiye'de Pozitivizm ve Siyaset”, Modern Türkiye’de Siyasi Düşünceİçinde. Cilt 3. Editör: Uygur Kocabaşoğlu. 452-65. İstanbul: İletişim Yayınları.

Paker, Murat.“Psikolojik Açıdan Önyargı ve Ayrımcılık”. Ayrımcılık: Çok Boyutlu Yaklaşımlarİçinde.Derleyen: Kenan Çayır \& Müge Ayan Ceyhan. 41-53. İstanbul: Bilgi Üniversitesi Yayınları..

Popper, Karl. 1990. “Toplum Bilimlerinde Öndeyi ve Kehanet”. Karl Popper'ın Bilim Felsefesi ve Siyaset Kurami Içinde. Editör: Bryan Magee.Çeviren: Şahin Alpay. 135-49.Ankara: Remzi Yayınları.

Said, Edward. 2003. Şarkiyatçılık: Batı’nın Şark Anlayışları. Çev: Berna Ünler. İstanbul: Metis Yayınları.

Scheler, Max. 2004. Hınç/Ressentiment. (Çev.) Abdullah Yılmaz. İstanbul: Kanat Yayınları.

Shayegan, Daryush. 1991. Yaralı Bilinç: Geleneksel Toplumlarda Kültürel Şizofreni. İstanbul: Metis Yayınları.

Tajfel, Henri. 1978. "Differentiation Between Social Groups: Studies in the Social Psychology of Intergroup Relations". Social Categorization, Social Identity and Social Comparisionİçinde. Derleyen: Tajfel, Henri. 61-76. London: Academic Press..

Talu, Umur. 1996. “Ülke İmajına Menfi Etki İstihbaratı”. Milliyet Gazetesi. 11 Haziran.

Taşkın, Yüksel 2013a.Milliyetçi Muhafazakâr Entelijansiya.İstanbul: İletişim Yayınları.

Taşkın, Yüksel. 2013b. AKP Devri. İstanbul: İletişim Yayınları.

Tunaya, Tarık Zafer. 2010. Türkiye ’nin Siyasi Hayatında Batılılaşma Hareketleri. İstanbul: Bilgi Üniversitesi Yayınları.

Yumlu, Konca. 1994. Kitle Illetişim Kuram ve Araştırmaları. İzmir: Nam Yayıncılık.

Vaes, Jeroen\&Paladino, Mario Paola\&Castelli, Luigi\&Leyens, Jacques-Philippe\& Giovanazzi, Anna. 2004."On The Behavioural Consequences of Infra-humanization: The Implicit Role of Uniquely Human Emotions in Intergroup Relations", Journal of Personality and Social Psychology. (87). 186-97.

Volkan, Vamık \& Itzkowitz, Norman. 2002. Türkler ve Yunanlılar: Çatışan Komşular. İstanbul: Bağlam Yayıncılı. 
İNCE, D. / Journal of Yasar University, 2015, 10(38) 6497-XXX

\section{Gazeteler}

Büyük Doğu, 18 Haziran 1956.

Milliyet Gazetesi.6 Temmuz 1995.

Milliyet Gazetesi. 26 Temmuz 1999.

Milliyet Gazetesi. 24 Ocak 2008. 